\title{
THE HISTORY OF FIRES IN OLD-GROWTH KOREAN PINE - BROADLEAVED FORESTS IN THE MIDDLE REACHES OF THE BIKIN RIVER (WESTERN SLOPE OF THE SYKHOTE-ALIN MOUNTAINS) ACCORDING TO DENDROCHRONOLOGICAL AND PEDOANTHRACOLOGICAL DATA
}

\author{
M. V. Bobrovsky \\ Institute of Physico-Chemical and Biological Problems in Soil Sciences of the Russian Academy of Sciences, \\ 2 Institutskaya street, Pushchino, 142290, Russia \\ E-mail:maxim.bobrovsky@gmail.com
}

\section{ИСТОРИЯ ПОЖАРОВ В СТАРОВОЗРАСТНЫХ КЕДРОВО-ШИРОКОЛИСТВЕННЫХ ЛЕСАХ СРЕАНЕГО ТЕЧЕНИЯ Р. БИКИН (ЗАПАДНЫЙ СКЛОН СИХОТЭ-АЛИНЯ) ПО АЕНАРОХРОНОЛОГИЧЕСКИМ И ПЕАОАНТРАКОЛОГИЧЕСКИМ ААННЫМ}

\author{
М. В. Бобровский \\ деление ФИЦ ПНЦБИ РАН, 14229о, Россия, Московская область, Пущино, ул. Институтская, 2 \\ E-mail: maxim.bobrovsky@gmail.com
}

Институт физико-химических и биологических проблем почвоведения Российской академии наук - обособленное подраз-

\begin{abstract}
The largest unfragmented tract of the rich-in-species old-growth Korean pine (Pinus koraiensis)broadleaved forests in the world is situated in the basin of the Bikin River. The history of these forests, including the fire history, is very important for understanding factors of dynamics of these forests and prognosis of their development under different climate change scenarios and land-use regimes. However, this history has not been studied in detail so far. Here we aim at reconstructing the local history of fires in the middle reaches of the Bikin River using dendrochronology and pedoanthracology (analysis of charcoal in the soil). We used treefall mounds to search for charcoal in soils; charcoal was selected from 34 treefall mounds, 14 charcoal samples were radiocarbon dated. The age of fire scars on trunks was determined using the increment borer method on 45 Pinus koraiensis individuals. We defined that the main factors responsible for charcoal transport to the mineral soils were past treefalls with uprooting and soil erosion. The most ancient soil charcoals date back to the Upper Neolithic, about 3450 cal BP. The remaining charcoal samples are mainly grouped into four clusters: about 2250, 1610, 1450 and $600 \mathrm{cal}$ BP. The increase of fire frequency is in good agreement with the previous results of lithologic-facies, botanical, spore-pollen and other analyses of bog sediments in the floodplain of the Bikin River. The earliest fires in the study area, which can be associated with human impacts, refer to the end of the first millennium (the time of the Bohai Kingdom). Fire scars were found on cores sampled from 39 out of 45 Pinus koraiensis individuals. The oldest Pinus we dated was 278 years old. Based on the cores, a fire chronology was built, covering the period from 1773 to 1993. Fires were marked for 36 years, while 10 years of them coincided in 3 and more cores. The periods with the highest frequency of fires are from 1937 to 1948 and from 1958 to 1980. We further followed possible connections between the frequency of fires and human activities. We also compared the fire chronology, data on precipitation and the number of fires in the Sikhote-Alin State Nature Reserve located closely to the study area. As expected, fires often occurred in the years with low precipitation or in the years following them. Preservation of a high species diversity of plants, especially the woody ones, with a significant frequency of fires in the study area can be explained by a complex relief determining the local fire spread and the presence of fire refugia. Soil charcoal analysis showed the existence of fire events from 3500 to 600 years BP and tree fire scars analysis showed the intensive fire history of the studied forests during the last 200 years. For the first time, fire regimes were reconstructed for Korean pine-broadleaved forest located on the slopes in the middle reaches of the Bikin River.
\end{abstract}

Keywords: charcoal, fire scars, tree uprooting, pit-and-mound topography, soil morphology, fire history, radiocarbon dating, Holocene, historical ecology, Russian Far East, Primorsky krai.

For citation: Bobrovsky M.V. The history of fires in old-growth korean pine - broadleaved forests in the middle reaches of the Bikin river (western slope of the Sykhote-Alin mountains) according to dendrochronological and 
pedoanthracological data. Russian Journal of Ecosystem Ecology. 2019;4(1). Available from: https://doi.org/10.21685/2500-0578-2019-1-2

Аннотация. В бассейне р. Бикин расположен крупнейший нефрагментированный массив старовозрастных кедрово-широколиственных лесов с Pinus koraiensis, которые характеризуются высоким биологическим разнообразием. История этих лесов, включая историю пожаров, важна для понимания факторов их динамики и прогноза их развития при изменениях климата и природопользования. До настоящего времени эта история мало изучена. Цель этого исследования - реконструкция локальной истории пожаров в среднем течении р. Бикин с использованием методов дендрохронологии и педоантракологии (анализа углей в почве). Бугры ветровалов были использованы для поиска углей в почве; из материала 34 бугров отобраны образцы углей, для 14 из которых определен радиоуглеродный возраст. Для определения возраста пожарных подсушин на стволах Pinus koraiensis использовали анализ кернов из 45 стволов. Показано, что основными факторами перемещения углей в минеральную почву были ветровалы и эрозия. Наиболее древние угли относятся ко времени верхнего неолита, около 3450 кал. л.н. Остальные образцы угля в основном сгруппированы в четыре кластера: около 2250, 1610, 1450 и 600 кал. л.н. Данные о периодах увеличения интенсивности пожаров хорошо согласуются с полученными ранее результатами литолого-фациального, ботанического, споровопыльцевого и других анализов седиментов и болотных отложений в пойме р. Бикин. Наиболее ранние пожары на исследованной территории, которые можно связать с деятельностью человека, относятся к концу первого тысячелетия н.э. (времени существования Царства Бохай). Пожарные метки встречены на кернах из 39 стволов Pinus koraiensis. Максимальный возраст Pinus 278 лет. На основе анализа кернов построена пожарная хронология, охватившая период с 1773 по 1993 год. Пожары отмечены для 36 лет, при этом для 10 из них наблюдается совпадение данных по 3 и более кернам. Периоды с наибольшей частотой пожаров - 19371948 и 1958-1980 годы. На основе анализа исторических источников об истории хозяйства в регионе рассмотрены возможные связи частоты пожаров с деятельностью человека. Пожарная хронология для исследуемой территории сопоставлена с данными о количестве осадков и числе пожаров на территории СихотэАлинского заповедника. Ожидаемо, что пожары часто случались в год с малым количеством осадков или в следующий за ним. Сохранение высокого видового разнообразия растений, в первую очередь древесных, при значительной частоте пожаров на исследованной территории может быть связано со сложным строением рельефа, определяющим локальное распространение пожаров и наличие пожарных рефугиумов. Таким образом, анализ углей в почве показал наличие пожаров в период с 3500 до 600 л.н., а анализ пожарных подсушин на деревьях показал интенсивную историю пожаров в изученных лесах за последние 200 лет. Впервые были реконструированы пожарные режимы для кедрово-широколиственных лесов на склонах в среднем течении р. Бикин.

Ключевые слова: древесный уголь, пожарные подсушины, ветровал, ветровальный микрорельеф, почвенная морфология, история пожаров, радиоуглеродное датирование, голоцен, историческая экология, Дальний Восток, Приморский край.

\section{Introduction}

Fire is one of the most important factors affecting the Earth's ecosystems and the biosphere as a whole. According to numerous climate change scenarios, the role of fires will increase in many of the world's regions $[1,2]$. It is necessary to know fire frequency, size, and intensity at different spatial and temporal scales aiming to assess the role of fires in the forming of a composition and structure of modern ecosystems, to forecast future scenarios, and to develop a fire management concept. Studies of recent decades have shown that fire-effects within the area of a particular biome can be not uniform, both in time and spatially [3]. In this regard, reconstruction of a regional fire history is essential for making it possible to assess the historical range of fire hazard variability and to determine the role of climate and anthropogenic impacts in fire ignition and in changing the successional tra- jectories of ecosystems. In this, the desired scale of the historical retrospective of fire regimes is the entire lifespan and spatial extent of an existing biome [4].

The Russian Far East (Primorsky Krai, Primorye) differs in landscapes and vegetation from the other Russian areas. Mountains, which mainly belong to the Sikhote-Alin Mountain system, make up $80 \%$ of the region. The Sikhote-Alin ridge extends for more than $1000 \mathrm{~km}$ from south-west to north-east (with a width of about $250 \mathrm{~km}$ ). The Ussuri taiga, which is boreal and boreal-nemoral forests with rich woody flora, prevails on the twothirds of the area. Among the taiga, Korean pine (Pinus koraiensis) - broadleaved forests are especially rich in their biological diversity. These forests include habitats of many endemic, rare and endangered plant and animal species. Fires play an important role in the dynamics of these forests; it was already indicated by the first researchers of the 
region N. M. Przhevalsky [5], A. F. Budischev, and M. I. Pyastushkevich in 1860-1880 [6]. The influence of fires on the Ussuri taiga ecosystems has been studied in many works [7-13], while the paleogeographic studies of Primorye were few until recently [14-16]; the long-term history of fire regimes in Korean pine-broadleaved forests was not investigated.

The largest unfragmented area of Korean pinedeciduous forests is located in the northern part of Primorsky Krai on the western macroslope of the Sikhote-Alin ridge in the middle reaches of the Bikin River. In historical times, these forests have not experienced significant anthropogenic impacts. Until recently, there were a few studies devoted to the history of landscapes in the upper [17] and in the lower [18] reaches of the Bikin River. In recent years, a large-scale research of the Late Pleistocene and the Holocene history has been carried out based on the study of bog sediments in the middle reaches of the Bikin River [19-23]. In this research, lithofacial, botanical, spore-pollen, and diatom analyses and radiocarbons dating as well were used to reconstruct the vegetation dynamics and the fire history in the valley of the Bikin River.

Besides the analysis of charcoal in lake and bog sediments, an important traditional method of fire history investigations is the fire scars dendrochronology, which allows reconstructing the history with the high temporal resolution [24-27]. In addition, in recent decades the study of charcoal in soils and sediments (pedoanthracology) has be- come widespread [28-33]. A significant feature of this method is the possibility to reconstruct discrete events in the history of local sites [34-38]. Generally, dendrochronological and pedoanthracological researches allow to receive the local data on fires in different landscape positions which are important for a comprehensive understanding of forest fire history. The aim of the present work is to supplement the existing reconstructions of the fire history of Korean pine-broadleaved forests located in the middle reaches of the Bikin River by dendrochronological and pedoanthracological data at different time scales.

\section{Methods}

\section{Study area}

Field data were collected in the middle reaches of the Bikin River, in the basin of its right tributary, the Amba River (Pozharsky District, Primorsky Kray) in September 2013 (Fig. 1). Currently this area is a part of the Bikin National Park, which was established in November 2015. The National Park occupies the upper and middle reaches of the Bikin River with an area of 1,160,459 hectares [39]. Our field data included fire tree cores and charcoal sampling in the soil. Sites for the soil sampling and tree stems for the boring were selected by the route method; the main part of the routes ran along the slopes of the Ulm Mound. The study area is closed to a square with sides of approximately 2.5 and $3 \mathrm{~km}$.

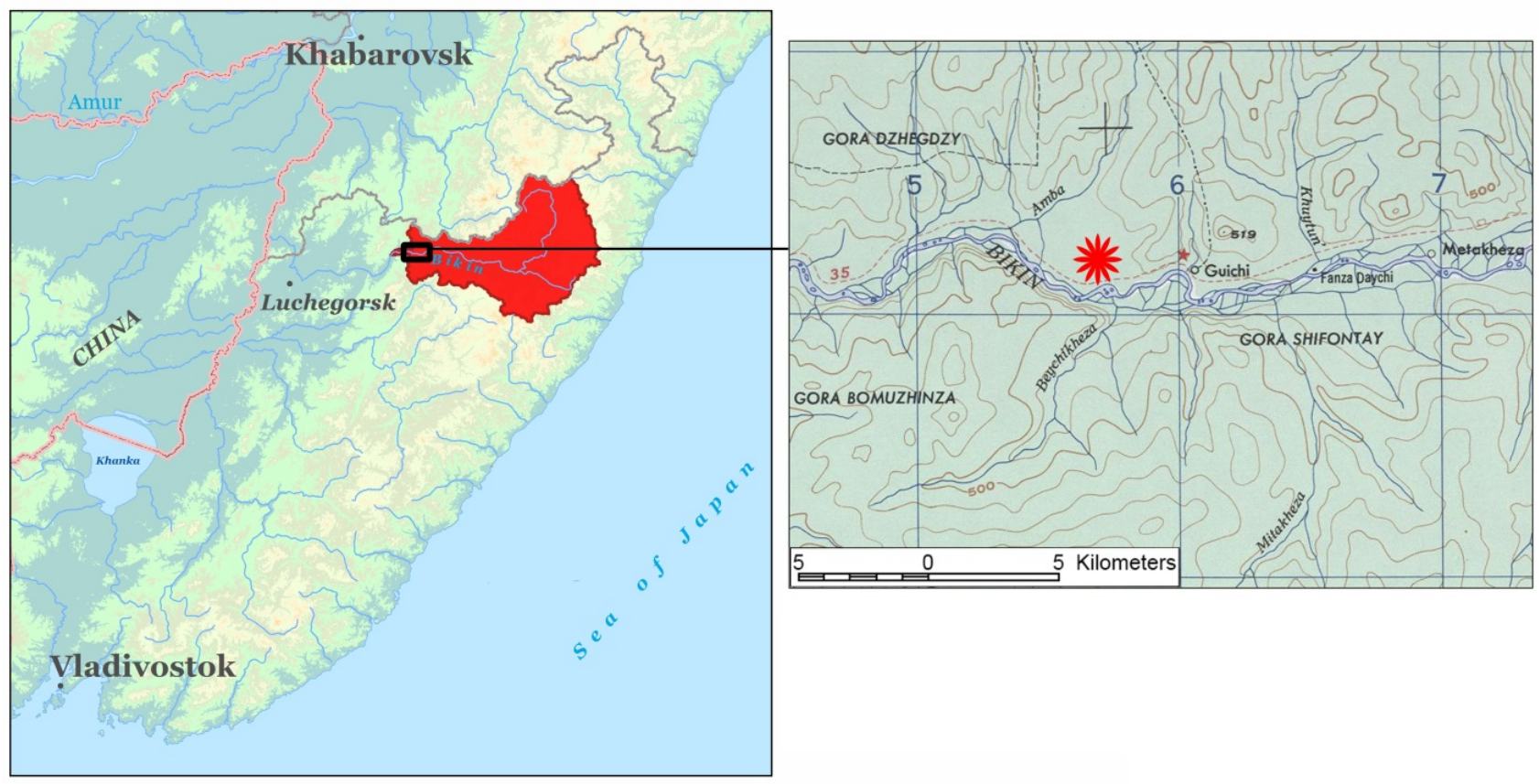

Fig. 1. Locations of the Bikin National Park (left, red area) and the study area (right, red star) [40]. North in the top here and in the next maps 


\section{Climate, relief and soil}

The climate of the region is monsoon with the continental features. According to the data of the Rodnikovaya weather station, the average annual temperature varies from $-0,8$ to $+1,1{ }^{\circ} \mathrm{C}$, in the area of the Olon weather station from $+0,5$ to $+1,5^{\circ} \mathrm{C}$. The average duration of the frost-free season amounts to 148 days, the smallest duration is 128 days, and the largest is 169 days. Precipitation is unevenly distributed across seasons; the most pre- cipitations falls in August; the annual sum varies from 642 to $1080 \mathrm{~mm}$ per year. Rainwater plays a major role in the water supply of the Bikin River [41].

The study area is located in the western macroslope of the Sikhote-Alin ridge, which is presented by dissected low mountains with the prevailing altitudes from 200 to $500 \mathrm{~m}$ above sea level. In the studied sites the highest elevation is $508 \mathrm{~m}$ (Kedrovaya Mound) and $310 \mathrm{~m}$ (the Ulm Mound); the water line of the Bikin River is $181 \mathrm{~m}$ asl. (Fig. 2).

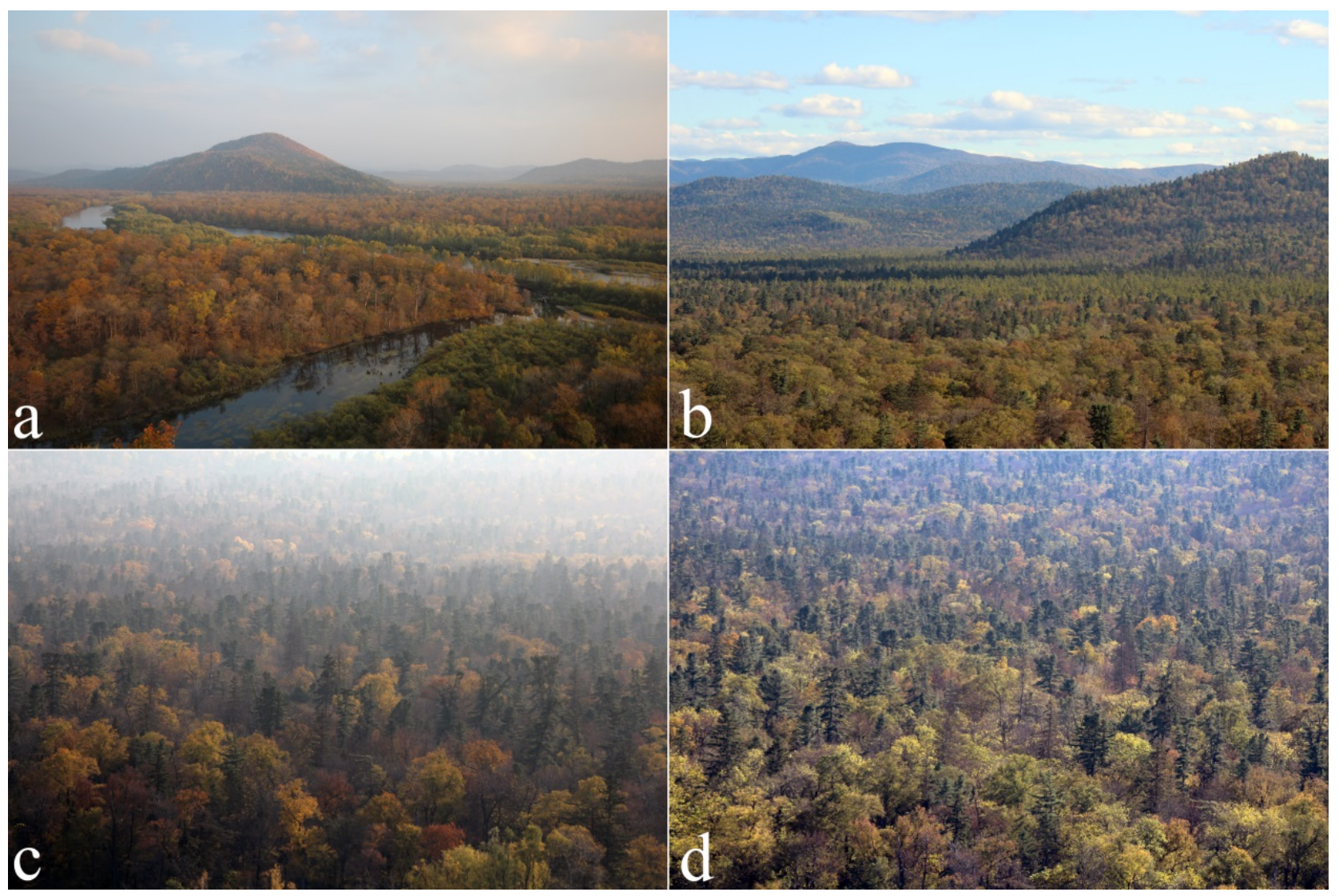

Fig. 2. Landscape view in the study area including a view to the Bikin River from the UIm Mound $(a, b)$ and Korean pine-broadleaved forests $(c, d)$

Structural metamorphic soils (Cambisols) predominate in the soil cover. Among them Burozems (Cambisols) with a humus horizon of 10 to $25 \mathrm{~cm}$ thick and $\mathrm{O}-\mathrm{A}-\mathrm{Bw}-\mathrm{C}$ profile prevail together with Dystric Cambisols without humus horizon, with a thick litter and $\mathrm{O}-\mathrm{Bw}-\mathrm{C}$ profile. Gleyic subtypes also occur. Total thick of the soil profile (i.e. the maximum depth of the tree root penetration) varied from 30 to $80 \mathrm{~cm}$. The soils are weakly skeletal (gravel) with stones of several centimeters size in the upper part of the profile and strongly skeletal with stones the size of first centimeters in the lower part of the profile.

\section{Vegetation}

Forests in the basin of the Bikin River belong to the following two geobotanical provinces: (1) the
South-Okhotsk dark-coniferous forest subregion, and (2) the Eastern-Asian coniferous-broadleaved region [10]. The first subregion is presented by fir-spruce and stone-birch (Betula ermanii) forests. The second region is presented by Korean pine-broadleaved forests, that form an independent altitude belt, and valley forests. The transition zone is presented by Korean pine-broadleavedspruce forests.

High-altitude zones are well expressed on the slopes of the mountains: a belt of Korean pinebroadleaved forests is developed at elevation from 200 to $600 \mathrm{~m}$; Korean pine-spruce forests occupy an elevation from 600 to $800 \mathrm{~m}$; fir-spruce forests occur above $800 \mathrm{~m}$ and till the peaks [42]. In the river valleys in the drained areas, broadleaved forests with Ulmus japonica and Fraxinus mandshurica dominate; the near-riverbed part is occupied 
by poplar-willow and Chosenia arbutifolia forests. On the river terraces there are wetlands occupied by larch bogs [mar'].

As was noted above, the study area is located from 200 to $500 \mathrm{~m}$ asl; Korean pine-broadleaved forests dominated by Pinus koraiensis grow there in the tops and ranges of the mounds at sites with well-drained soil (Fig. 3,a,b). Pinus koraiensis prevails in the overstorey, Betula daurica, Tilia amurensis, T. mandghurica, and Ulmus lasiniata sometimes also occur. Crowns cover $60-80 \%$ of the overstorey. In the understorey Acer tegmentosum, A. mono, Eleutheroccocus senticosus, Philadelphus tenuifolius, Actinidia kolomikta, Ribes hispidum, R. maximowiczii, Rhamnus daurica, Lonicera chrysantha and others occur. Cover of the understorey is 40-60 \%. Athyrium spinulosum, Dryopteris amurensis, Maianthemum dilatatum, and Oxalis acetosella dominate in the field layer with the total cover from 10 to $40 \%$.
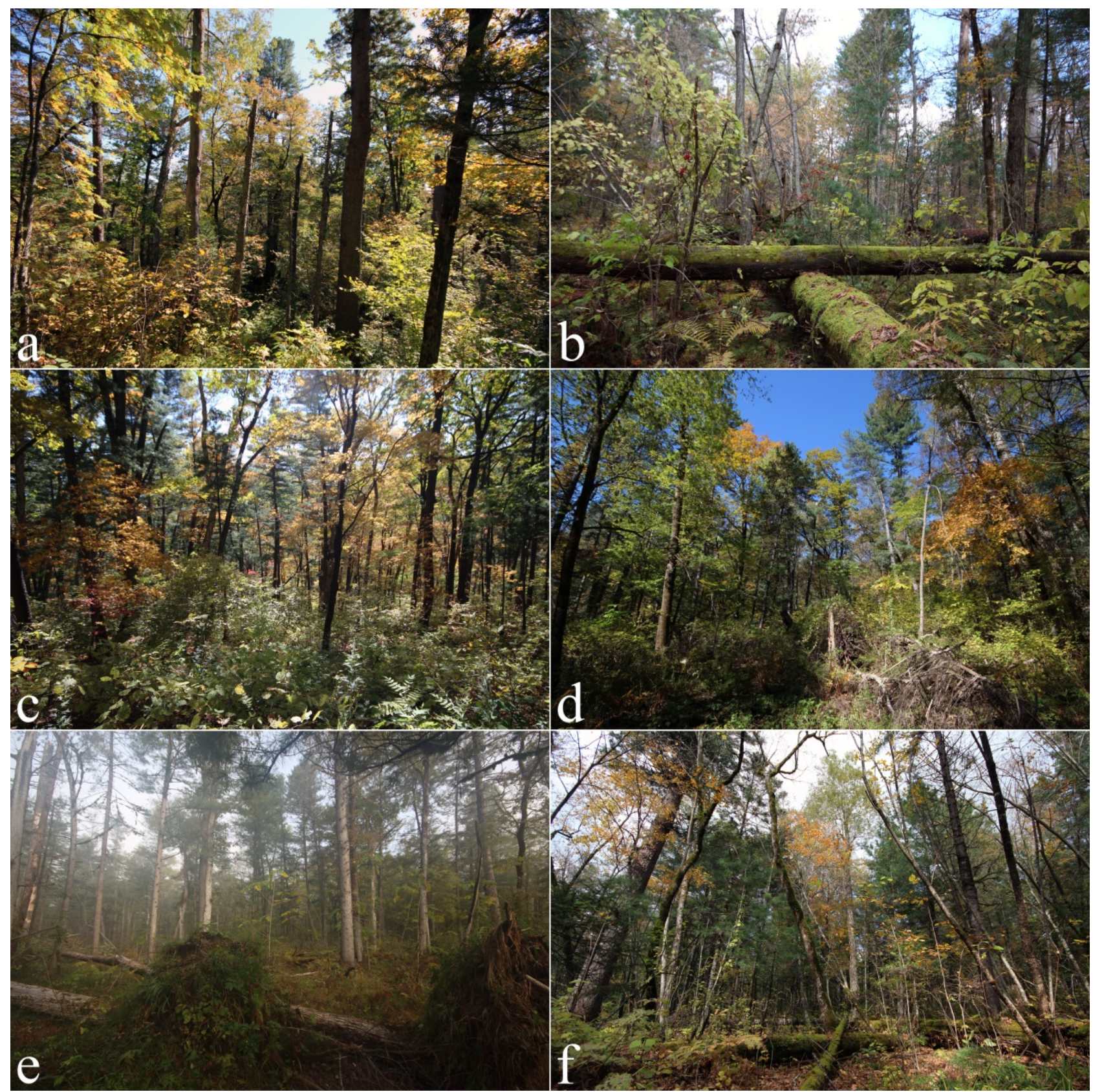

Fig. 3. Old-growth forests in the study area: $a, b$ - Korean pine-broadleaved forests dominated by Pinus koraiensis at the tops of the mounds; $c, d$-Korean pine-broadleaved forests dominated by broadleaved species on the slopes of the mounds in sites with well-drained soil; $e, f$ - Korean pine-mixed forests dominated by dark-coniferous and broadleaved species in wet areas of the slopes and at the foot of the mounds

Main part of the study area is occupied by Korean pine-broadleaved forests dominated by broad- leaved species; they grow on the slopes of the mounds in sites with well-drained soil (Fig. 3,c,d). 
Pinus koraiensis dominates in the overstorey; Tilia amurensis, Betula costata, Fraxinus mandshurica, Acer tegmentosum, A. mono, Ulmus lasiniata, Populus tremula, and Quercus mongolica often occur; Juglans mandshurica, Phellodendron amurense, Tilia mandshurica, and Taxus cuspidate rarer occur. Crown cover varies from 50 to $80 \%$. In the understorey Eleutheroccocus senticosus, Philadelphus tenuifolius, Acer mono, A. tegmentosum, and $A$. ukurunduense dominate. Cover of the understorey varies from 30 to $60 \%$. Carex siderosticta, Hylomecon vernalis, Dryopteris crassirhizoma, Athyrium spinulosu, Maianthemum dilatatum, etc. occur in the field layer with the total cover $30-60 \%$.

Korean pine-mixed forests dominated by darkconiferous and broadleaved species grow in wet areas of the slopes and at the foot of the mounds (Fig. 3,e,f). Pinus koraiensis, Tilia amurensis, T. mandghurica, Betula costata, Fraxinus mandshurica, Ulmus lasiniata, Picea ajanensis, P. koraiensis, Abies nephrolepis and others occur in the overstorey with the total crown cover from 50 to $80 \%$. Philadelphus tenuifolius, Eleutheroccocus senticosus, Alnus hirsute, Maackia amurensis, Corylus mandshurica, etc. dominate in the understorey with the total cover 30-50\%. In the field layer Carex siderosticta, Calamogrostis langsdorfii, Athyrium pycnosorum, Equisetum hyemale, Matteuccia japonica, Diplasium sibiricum, Chrysosplenium pilosum, Adiantum pedatum and others prevail; cover of the layer varies from 60 to $90 \%$.

Evidence of old-growth forest, such as deadwood, gaps in the canopy, and pit-and-mound topography formed by treefalls with uprooting, is common, but old stumps which are traces of cutting also often occur.

\section{Vegetation history}

Korean pine-broadleaved forests situated in north-eastern Asia are remnants of the Turgai flora that once existed across the entire territory of Eurasia [43]. These forests cover the southern part of the Russian Far-East, the north-eastern part of China, as well as parts of the Korean peninsula and Japanese islands [44].

Razzhigaeva et al. [19-23] have recently reconstructed the Late Pleistocene and the Holocene history of vegetation in the middle reaches of the Bikin River based on the study of sediments in bogs located in the floodplain and in the terraces of the river. Changes over the past 4500 years have been studied most thoroughly. The study recognized the main stages of vegetation development in the region over this time period as following [19, 21]:

- 4385-3610 calibrated years ago (cal BP): the appearance of Pinus koraiensis in the forest of lowlands, the spread of Korean pine-deciduous forests;

- 3610-3290 cal BP: the warming; further spread of Korean pine-deciduous forests;

- 3290-2590 cal BP: reduction of the area of Korean pine-broadleaved forests, increase of the birch forests area; the increase in fire frequency, the cooling about 2800-2600 cal yr BP;

- 2590-1060 cal BP: the dynamic period; rapid changes in biotic components inter alia through the action of fires; the cooling 2590-2372 cal yr BP; a sharp increase in the participation of Pinus koraiensis in the vegetation, and an increase in the relative abundance of birch trees by the end of the period;

- after 1060 cal BP: the small Holocene climatic optimum (the warming), an increase in the participation of broadleaved trees, and an increase in participation of fir about $870 \mathrm{cal} \mathrm{yr} \mathrm{BP}$.

There was no significant effect of the small glacial period on vegetation in the middle reaches of the Bikin River;

- 690-570 cal BP: the decrease in participation of broadleaved trees;

- 570-343 cal BP: the beginning of the cold phase, the increase in the proportion of the pioneer deciduous (small-leaved) trees;

- 245-196 cal BP: the sharp increase in the proportion of Pinus koraiensis.

Thus, according to Razzhigaeva et al. [19, 21], during the Holocene there were no dramatic changes in the composition of the woody plants: in the short-term cooling periods, the participation of dark coniferous species and birch increased, and in the warming periods the participation of broadleaved trees increased.

\section{Human}

A detailed archeological and historical knowledge about the area is crucial for the understanding of its fire history. While the fact of fires itself is recorded as charcoals in soils and fire scars on trees, an accompanying record on the land management can offer nuanced details about the causes of fires and controls on their spatial distribution. Here we assembled archaeological and historical record of the Bikin River area that would have influenced the local fire history.

For the area of the lower reaches of the Bikin River and the adjacent territories, there are about 30 archaeological sites of different times known: of the Stone Age (5 thousand years BC), the Iron Age, and the Middle Ages [45], whereas in the middle reaches of the Bikin River only a few archaeological sites referenced to the Middle Ages are known $[46,47]$. The area of the modern Rus- 
sian Primorye was a part of several large feudal states: the Bohai (Balhae) kingdom (628-926), the Khitan State (907 to 1125) and the Jin dynasty (1115-1234), which consistently existed including our study area from the 7 th to 13 th centuries [48]. The archeological site of ancient settlement Kanchuga with the earthwork characteristics similar to the Bohai fortifications from the 8th to 10th centuries was recently described near our study area, between the Bikin River's tributaries: the Amba and the Khutkhun Rivers [47]. The Jin (/dzIn/) dynasty, officially known as the Great Jin, or Jurchen Jin, was established by the Jurchen. Jin control over most of North China lasted until the Mongol invasion in 1234. In these feudal states, main types of economy were cattle breeding and agriculture.

The descendants of the Jurchens are considered to be the Udege (Udekhe), Orochs, and Nanai people (Golds), which were the indigenous population of Primorye at the beginning of the Russian colonization of the region in 1860 [49]. The indigenous population amounted to several thousand people at that time; main occupations of those people were hunting, fishing, and gathering. Chinese were also a significant part of the region population.

Primorye became a part of the Russian Empire according to the Treaty of Peking (The First Convention of Peking). Materials of the Russian expeditions led by A. F. Budyshchev (1859-1864), I. P. Nadarov (1882-1883) and V. K. Arsenyev (1907-1908) contain the first detailed descriptions of the population and nature of the Bikin River ba$\sin [6,49]$.

Russian colonization of Primorye has started with travelling by land; the relocation by sea began only from 1882. In 1901 the Ussuriisk branch of the Trans-Siberian Railway was opened; this connected the European part of Russia and Vladivostok. Forest was required for the construction of this railway. It is known that from 1894 or 1895 winter wood was harvested in the basin of the Bikin River, and the woods were floated down the river in summer [49]. In 1894, the Bikinskaya railway station was built. Next to it, Stanitsa Bikinskaya village and the village of Orenburgskoe (the city $\mathrm{Bi}$ kin since 1938) were formed. The lower reaches of the Bikin River were settled mainly by Cossacks. According to V. K. Arsenyev, from Sigou (now the village Yasenevyi, about $25 \mathrm{~km}$ downstream from the study area) to Orenburgskoe village, there was a good sledge road [49] that testifies a fairly welldeveloped communication between settlements.

In 1905, in Stanitsa Bikinskaya, the timber producer L. Sh. Skidalsky began construction of a timber mill, which began work in 1907, annually processing about $20,000 \mathrm{~m}^{3}$ of wood. In 1924, the plant processed $50,000 \mathrm{~m}^{3}$ of wood per year [49].
In 1918-1920, Old Believers came to the upper reaches of the Bikin River from the coast of the Sea of Japan and formed the village of Ulungu (now Okhotnichy, about $100 \mathrm{~km}$ upstream from our study area). Two monasteries were built: one on the Zeva River, the second on the Kamenny Key Stream. In 1922 the Soviet power was established in Primorye; the territory became a part of the RSFSR. From 1930, the Soviet Union enforced the collectivization of its agricultural sector. In 1932 the Old Believers rebellions began, which were brutally suppressed in $1932-1933$ by the authorities with the participation of the NKVD troops.

With the arrival of the Russian population, aboriginal people began to use agriculture, and they set up vegetable gardens. For example, in the notes of 1908 V. K. Arsenyev pointed out that in several versts (former Russian unit of measurement equal to $1,06 \mathrm{~km}$ ) from Metakheza camp there is a small Oroch camp of Tugulu (perhaps it is Takholo, as Panichev notes in [49]) located on the right bank of the Bikin River. In Tugulu, as well as in Metakheza, the Orochs cut down the forest, cleared a small area and set up their gardens among the stumps [49]. Our study area is located between the places of those former settlements in approximately $7 \mathrm{~km}$ from each (see Fig. 1). In 1931 there were 13 Udege camps in the valley of the Bikin River; it is known that four of those camps were located higher than Metaheza along the Bikin River. In 1934-1936, the authorities forcibly relocated all aboriginal people from their camps to the villages of Olon, Syain, and Metaheza, where log houses according to the Russian model were built. Then, in 1938, aiming at consolidating settlements for simplifying the control, Metakheza village was "resettled" with houses and residents into Syain [49]. Additionally, in 1937-1938, residents of Korean and Chinese nationalities were forcibly deported from Primorye.

In the 1930s, the Bikin timber industry enterprise was established and in 1938 a logging station was opened in the village of Verkhny Pereval. In 1947, an area for harvesting the bark of the Amur cork tree (Phellodendron amurense) was also established there. The most active logging was carried out in 1960-1970 on the lower reaches of the Bikin River. All woods harvested in the valley of the Bikin River were floating by the river. The highest point from which the timber floating began was the village of Sigou (Yasenevyi).

In the late 1960s, logging began in the basin of the Takholo River, in the hunting areas of the Udeges. As a result of the appeal of local residents and scientists in 1971, the RSFSR Council of Ministers officially secured the Korean pine forests of 
the middle part of the Bikin River valley as a hunting ground and as an area of the cedar-nutproduction zone. The boundary of this zone ran along the watershed between the Takhalo and the Amba Rivers (the tributaries of the Bikin River). Upstream of the Bikin River, logging was prohibited [50]. On the whole, the establishing of cedarnut-production zones, which began in 1953, made it possible to avoid the overwhelming logging in the Korean pine forests of the Far East on an area of 1.02 million hectares. The Bikinskaya (Verkhneperevalnenskaya) nut-production zone had the largest area, most of which became a part of the Bikin National Park in 2015.

It should be noted that in Fig. 1 (right), a fragment of the topographic map [40] compiled by U.S. Army Map Service from maps of Japanese General Staff in 1942-1947 is presented. There are native (Manchu-Tungus) and Chinese place names (toponyms). After the Sino-Soviet border conflict on the Damansky Island (Zhenbao Island) in 1969, there was a massive renaming of names of Chinese origin and many local place names in the Primorsky Krai in 1972. For example, the Mitakhez River is now the Lesnukha River. This moment of geographical renaming should be considered when studying ecological history.

\section{Charcoal sampling and analysis}

Charcoal pieces from the soil are usually taken from soil profiles or by boring. In the study area these regular methods of charcoal sampling were not effective, because the gravel soils had a very small profile thickness (the thickness of the fine earth layer is the first tens of centimeters, often less than $20 \mathrm{~cm}$ ) and the soils were saturated with water. In those conditions, the most efficient method of charcoal search and selection in the soil turned out to be an exploration of treefall mounds which were recently formed (Fig. 4). A treefall mound is a part of the soil cloud which is raised by roots when the tree falls with uprooting. As long as the mound keeps its shape, it is possible to define the initial localization of the charcoal pieces found in the treefall mound: to determine the soil horizon and the depth of the charcoal occurrence. Charcoal was taken from 35 treefalls which were found in the study area.

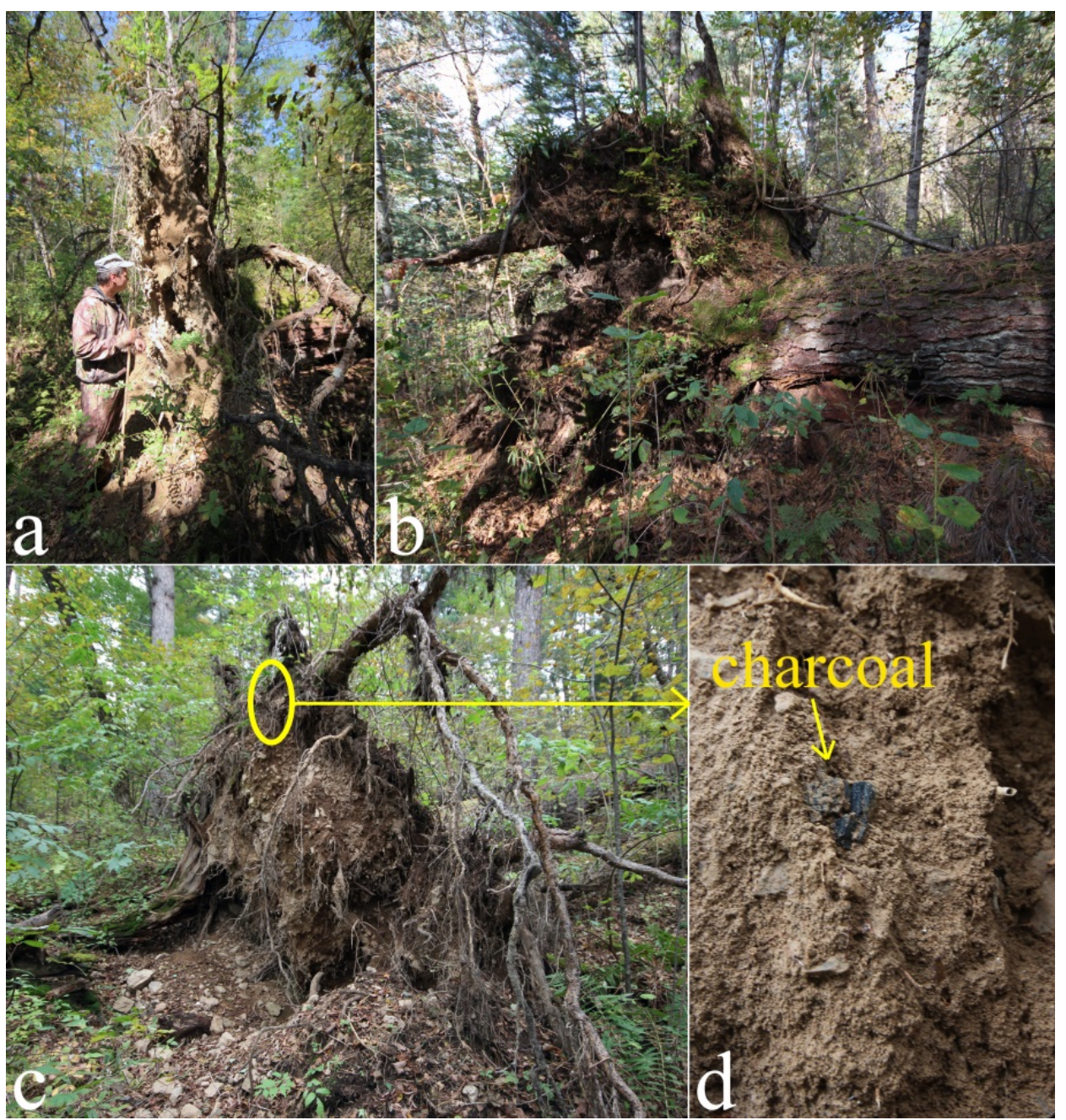

Fig. 4. Treefall mounds (from $a$ to $c$ ) and charcoal pieces in the mound (d) 
Fourteen largest charcoal specimens from the soil were radiocarbon-dated in the Institute of geochemistry and geophysics of the National Academy of Sciences of Belarus (IGSB). Radiocarbon age of the charcoal was determined by the liquid scintillation counting (LSC). Standard techniques including acid-base-acid (ABA) treatment were used. The samples were placed in $1 \mathrm{M} \mathrm{HCl}$ and heated to $80{ }^{\circ} \mathrm{C}$ for $1 \mathrm{~h}$, centrifuged and decanted. Then the samples were washed with $0.1 \mathrm{M} \mathrm{NaOH}$ and treated with dilute $\mathrm{HCl}$, then washed with deionized water and dried at $105{ }^{\circ} \mathrm{C}$. The activity of $14 \mathrm{C}$ was determined in benzene using a Quantulus 1220 liquid scintillation counter. The ${ }^{14} \mathrm{C}$ dates were calibrated using the program Calib 13.0 and the calibration dataset Intcal13 [51]. Calculations were done at $2 \sigma$ level.

\section{Fire scar sampling and analysis}

The dendrochronological method is often used to define ages of trees and to date forest fires as well [24-26, 52-54]. Disks from harvested trees are usually analyzed for this $[52,53,55,56]$. However, in a case of old trees and old-growth forests, tree harvesting is an ethically wrong research method as it causes undue damage to forest ecosys- tems. Fortunately, this method is not allowed to use in nature protected areas.

An alternative increment borer method for determining fire history in coniferous forests was suggested by Barrett and Arno [57]. During the sampling, we were not aware of this work, but we used a similar approach that mainly coincided with Barrett and Arno's method.

To determine the time of past ground fires, we took cores of tree individuals that had fire scars on the trunk. The scars are dead cambium and wood, which to some extent are covered by the wound meristem from the edges of the wound. As a rule, fire scars are located on the trunks from a side opposite to the front of the fire movement: on the leeward side of the trunks, where the turbulence of hot gases occurs and the flame lasts longest. Fire scars may also form in a proximity to patches with a thick litter layer. Small fire scars often heal fully over time. Fire scars that are more than $20-30 \mathrm{~cm}$ wide are usually visible on the tree until the end of its life. Increment borer method includes combinations of scar boring and face/back boring to date individual fire scars (Fig. 5). The method can be best used on long-lived tree species that survive fires and resist decay after fire damage due to high resin content. In our study, we chose to use Pinus koraiensis, which fits these properties.

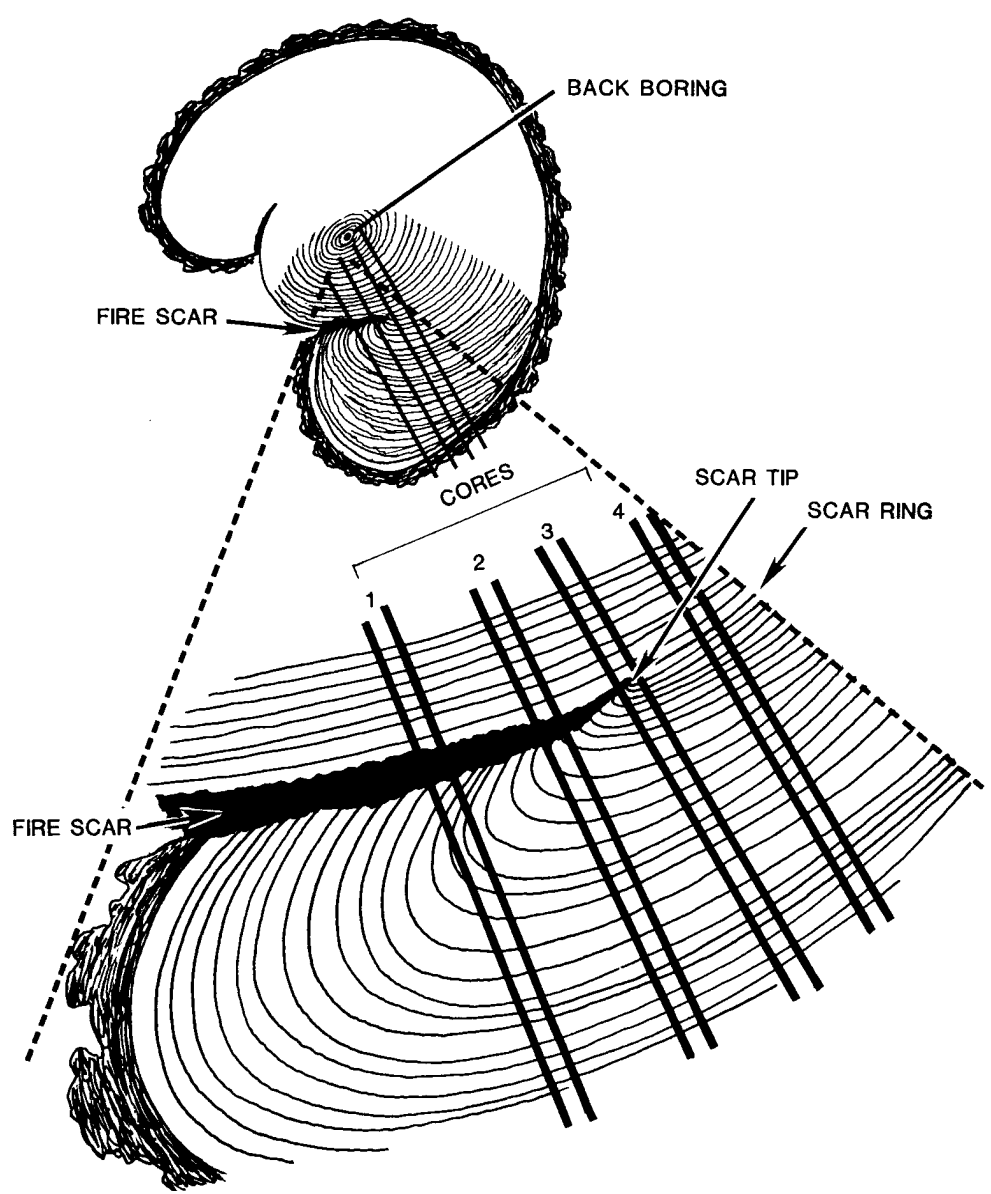

Fig. 5. Scar-boring procedures illustrated on a hypothetical cross-section of a single-scarred tree [57] 
Forty-five individuals of Pinus koraiensis were selected for dating the past forest fires. From one to four tree cores were taken from one tree. Most sampled trees showed external evidence of callus tissue and charcoal from past fires (Fig. 6). We recorded sample locations with a GPS unit and photographed them to document the scarring.

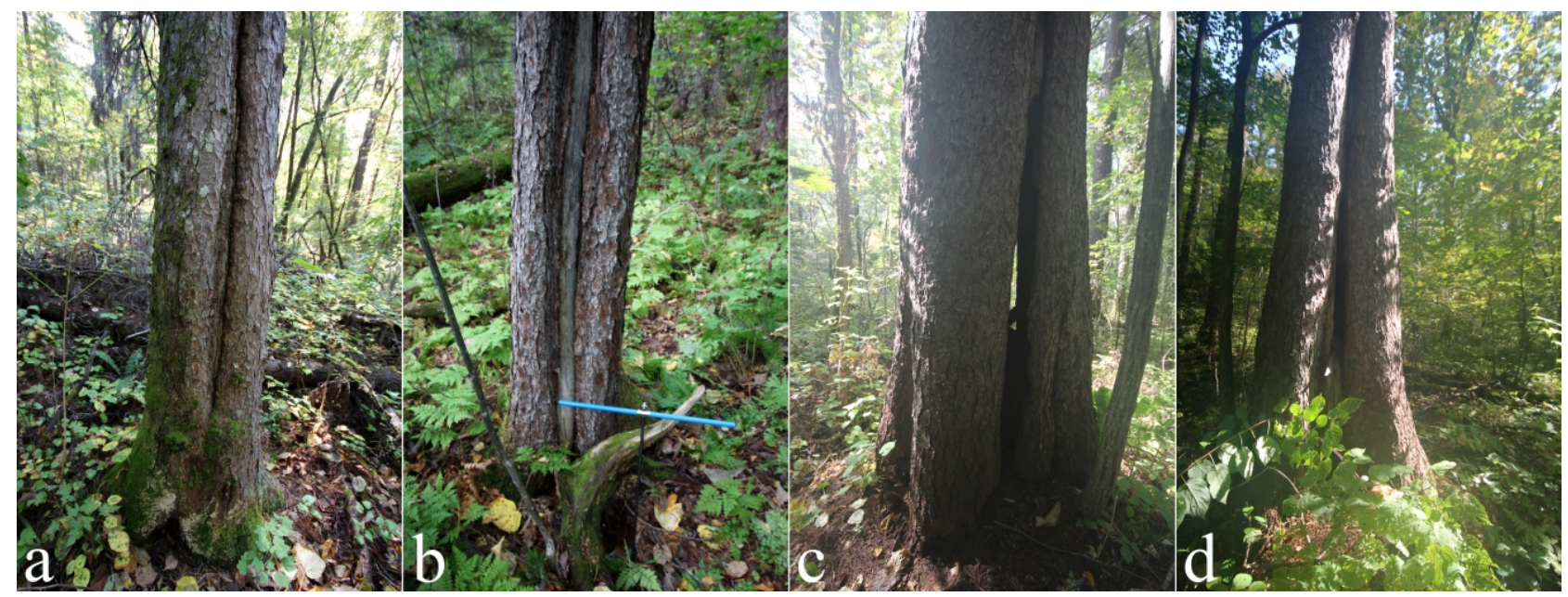

Fig. 6. Fire scars on the Pinus koraiensis trunks located on the slopes of the Ulma Mound

\section{Results}

\section{Soil charcoal stratigraphy and radiocarbon dating}

Several tens of treefall mounds were investigated and charcoal was found in 34 mounds (Fig. 7). Most of these treefall mounds were located in the upper and middle parts of the slopes; there was no charcoal in treefall mounds situated in the valleys of streams. In general, we can speak of a relatively uniform distribution of charcoal in the soils over the studied area; probably "white spots" are mainly related to the absence of treefalls suitable for searching charcoals. In addition to charcoal in the treefall mounds, we found one charred stump and one charred deadwood (Fig. 8); also charcoals were found under the litter.

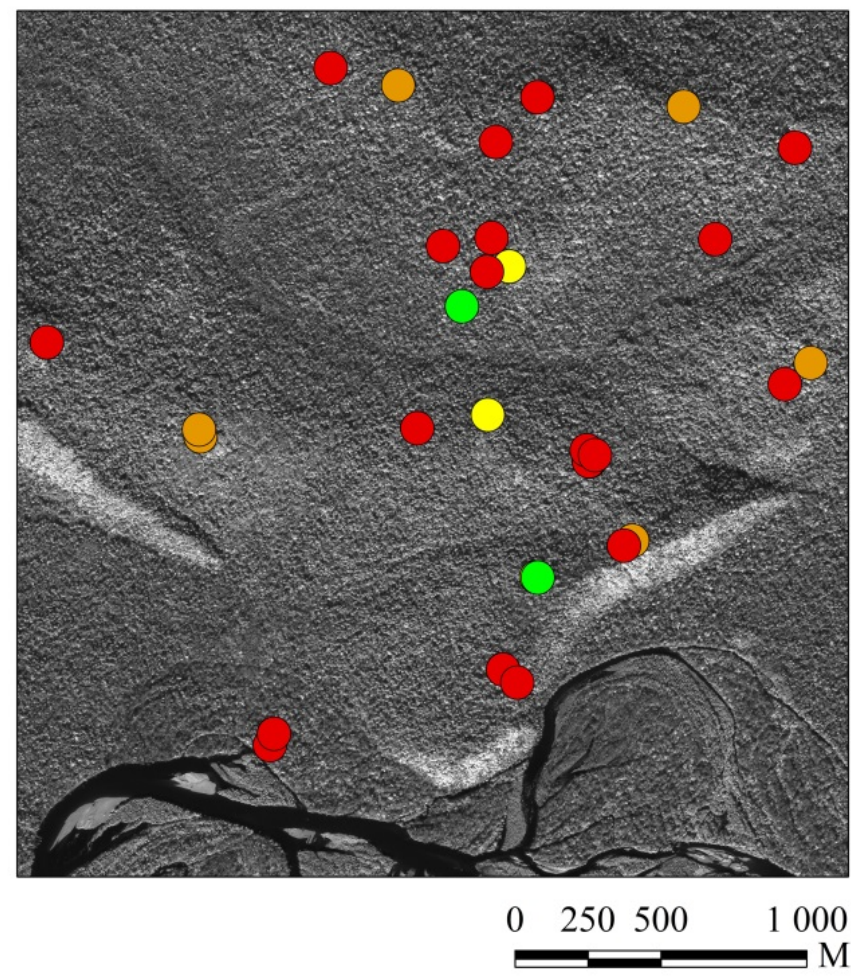

\section{burnt stump, deadwood under litter A horizon Bw horizon}

Fig. 7. Spatial placement of samples with different charcoal positions on a high-resolution satellite image. A few studied points are located out of the photo, in the west 


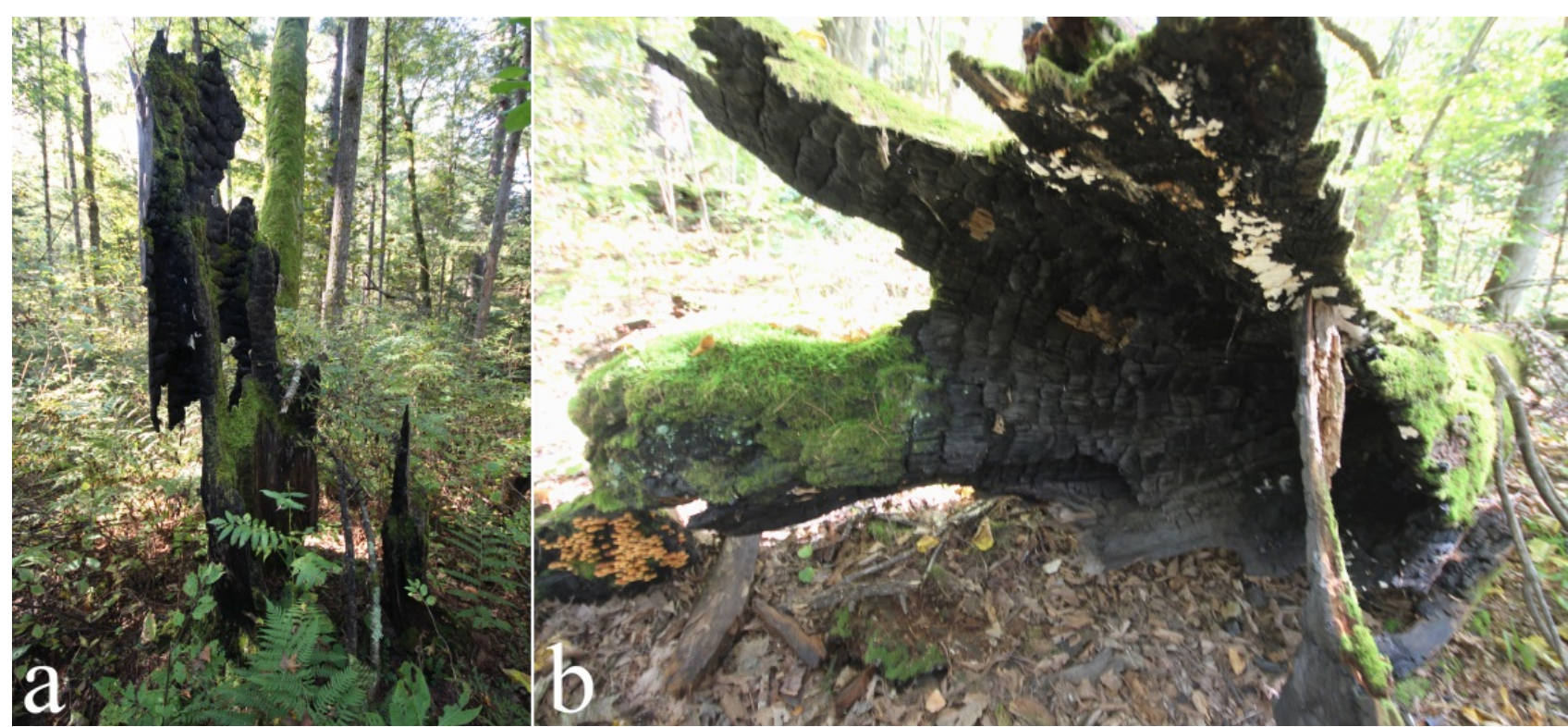

Fig. 8. Charred stump ( $a$ ) and charred deadwood ( $b$ ) of Pinus koraiensis

In six treefall mounds, charcoal pieces were found in the humus horizons (usually at depths up to 10 or $15 \mathrm{~cm}$ ). In most treefall mounds, charcoals were found only in the illuvial horizon $\mathrm{Bw}$, at depths from 10 to $50 \mathrm{~cm}$. In the root-soil clod, charcoal pieces were often found under the large supporting roots of trees. Comparatively seldom charcoals were visible on the back wall of the treefall mound (opposite to the lying trunk).

The radiocarbon dating of 14 charcoal samples showed that the charcoal age varied from $587 \pm 47$ to $3720 \pm 113$ cal BP (Table 1). The ranges $(2 \delta)$ of radiocarbon dates formed several clusters (Fig. 9): about 600 cal BP (samples 5 and 31); about 1450 cal BP (the Middle Ages, samples 4, 13, and 24); about 1610 cal BP (late Iron Age border and the Middle Ages, samples 14, 15, and 23); and about 2250 cal BP (Early Iron Age or Paleometal Age, samples 22, 26, and 29). Probability peaks of the sample 19 are located between the first and the second clusters. Samples 7 and 8 have the most ancient dates, dating back to the time of the Upper Neolithic. There are no dated samples that belong to the Modern Period (the last 500 years). In general, there was no correlation between the age of charcoals and the depth of their locations in soil.

Table 1

Radiocarbon dates for charcoals from the study area in the middle reaches of the Bikin River calibrated according to Reimer et al. [51] using IntCal13

\begin{tabular}{|c|c|c|c|c|c|c|}
\hline Sample & $\begin{array}{c}\text { Soil } \\
\text { horizon }\end{array}$ & Matter & Lab. code & $\begin{array}{c}\text { Lab. radiocarbon } \\
\text { age (BP) }\end{array}$ & $\begin{array}{c}\text { Cal radiocarbon } \\
\text { age (BP) }\end{array}$ & Cal BC/AD \\
\hline 4 & Bw & Charcoal & IGSB-1612 & $1450 \pm 80$ & $1444 \pm 78$ & $506 \pm 78 \mathrm{AD}$ \\
\hline 5 & $\mathrm{Bw}$ & Charcoal & IGSB-1629 & $720 \pm 60$ & $654 \pm 62$ & $1296 \pm 62 \mathrm{AD}$ \\
\hline 7 & $\mathrm{Bw}$ & Charcoal & IGSB-1611 & $3450 \pm 90$ & $3720 \pm 113$ & $1770 \pm 113 \mathrm{BC}$ \\
\hline 8 & $\mathrm{~A}$ & Charcoal & IGSB-1589 & $3050 \pm 70$ & $3247 \pm 93$ & $1297 \pm 93 \mathrm{BC}$ \\
\hline 13 & $\mathrm{Bw}$ & Charcoal & IGSB-1588 & $1420 \pm 60$ & $1340 \pm 40$ & $610 \pm 40 \mathrm{AD}$ \\
\hline 14 & $\mathrm{Bw}$ & Charcoal & IGSB-1609 & $1690 \pm 150$ & $1615 \pm 63$ & $335 \pm 63 \mathrm{AD}$ \\
\hline 15 & $\mathrm{Bw}$ & Charcoal & IGSB-1590 & $1680 \pm 60$ & $1602 \pm 75$ & $348 \pm 75 \mathrm{AD}$ \\
\hline 19 & $\mathrm{Bw}$ & Charcoal & IGSB-1628 & $1290 \pm 100$ & $1191 \pm 98$ & $759 \pm 98 \mathrm{AD}$ \\
\hline 22 & $\mathrm{Bw}$ & Charcoal & IGSB-1610 & $2260 \pm 100$ & $2271 \pm 122$ & $321 \pm 122 \mathrm{BC}$ \\
\hline 23 & $\mathrm{Bw}$ & Charcoal & IGSB-1592 & $1690 \pm 60$ & $1612 \pm 71$ & $338 \pm 71 \mathrm{AD}$ \\
\hline 24 & $\mathrm{Bw}$ & Charcoal & IGSB-1630 & $1530 \pm 80$ & $1437 \pm 78$ & $513 \pm 78 \mathrm{AD}$ \\
\hline 26 & $\mathrm{Bw}$ & Charcoal & IGSB-1593 & $2290 \pm 80$ & $2303 \pm 115$ & $353 \pm 115 \mathrm{BC}$ \\
\hline 29 & $\mathrm{Bw}$ & Charcoal & IGSB-1591 & $2200 \pm 70$ & $2210 \pm 89$ & $260 \pm 89 \mathrm{BC}$ \\
\hline 31 & $\mathrm{~A}$ & Charcoal & IGSB-1631 & $560 \pm 60$ & $587 \pm 47$ & $1363 \pm 47 \mathrm{AD}$ \\
\hline
\end{tabular}


Radiocarbon date

Laboratory code

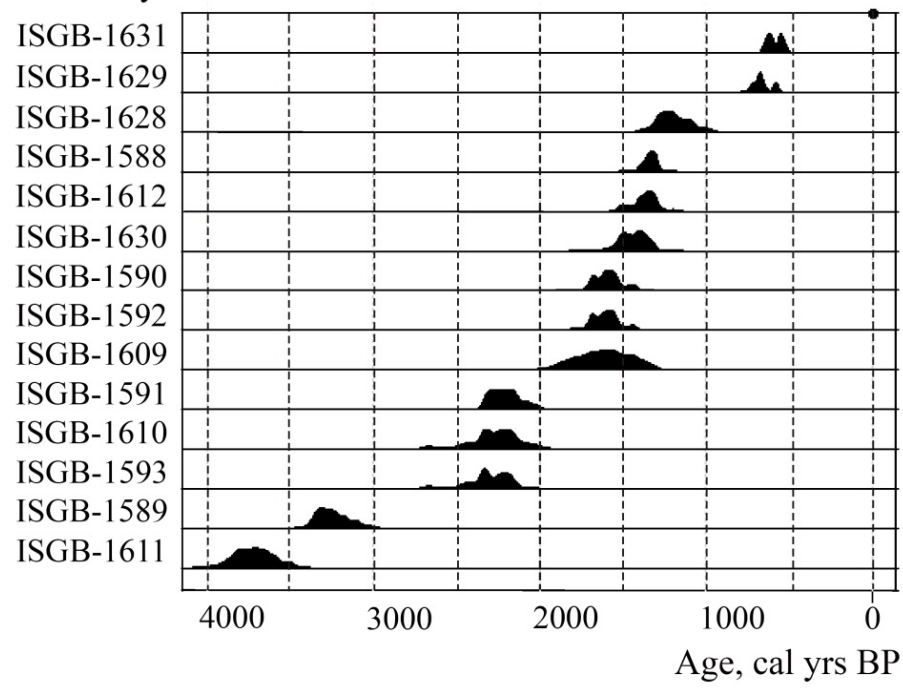

Fig. 9. Probability curves of calibrated radiocarbon dates for charcoals from the study area in the middle reaches of the Bikin River

\section{Fire scars}

Increment cores were taken from 45 individuals of Pinus koraiensis; fire marks were found in the cores from 39 individuals. We should note that there were difficulties in using of dendrochronological method in the studied region by reason of the high rates of Pinus koraiensis growth leading to the formation of broad annual wood increments. As a result, the wood of many individuals has a loose structure; upon dying off due to fire, such wood does not form a "fire mark", but turns into dust (rot), in which it is impossible to distinguish traces of annual increments. Wood rot was found in $65 \%$ of the tree cores. For such tree individuals, we could define only the age of the last scar and could not define the full age of the individual.
Spatial distribution of trees with one to five distinguishable fire marks is shown in Fig. 10. This area is noticeably smaller than the area where charcoal in the treefall mounds was found (see Fig. 7). Trees with traces of ground fires are unevenly distributed over the study area. Partly, this may be affected by non-uniform coverage of the area by routes during the study (because of a complex relief), but the obtained distribution of the trees with fire scars mainly reflects their actual frequency of occurrence in the area. A significant part of Pinus koraiensis individuals with fire scars is located on local elevations: on the crest of the Ulm Mound (southeast part) and the bends of the slopes. These are the most drained areas for which the probability of fires is the greatest.

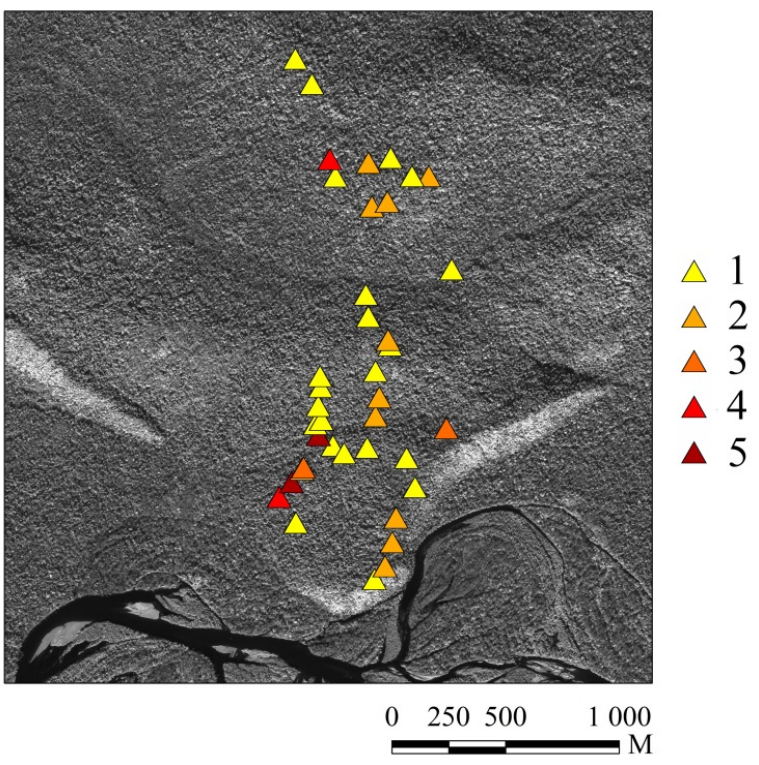

Fig. 10. Spatial distribution of Pinus koraiensis with different number of fire scores 
Fire scar history data with the number of fire events is presented in Fig. 11. The oldest tree was 278 years old (it has grown since 1735). Data for five Pinus koraiensis individuals are available from 1810 and for ten individuals from 1845 . Within the studied time period, fires were identified in 36 years; data on 10 years from them were obtained from 3 and more cores of different trees. The oldest identified fire dates back to 1773 . From this time, the mean interval between fires is 6.7 years (if to count all fire marks), and 24.1 years (if to count only years with coincided fire marks). The conglomerate density of the whole time interval does not seem to be completely homogeneous. There are several periods with an elevated frequency of fires and intervals without fires separating them. The first fire peak belongs to 1846 . The time intervals $1937-1948$ and 1958-1980 are the periods with the highest frequency of fires with no fires in between them, and only two fire marks were identified after 1980, both occurring in 1993.

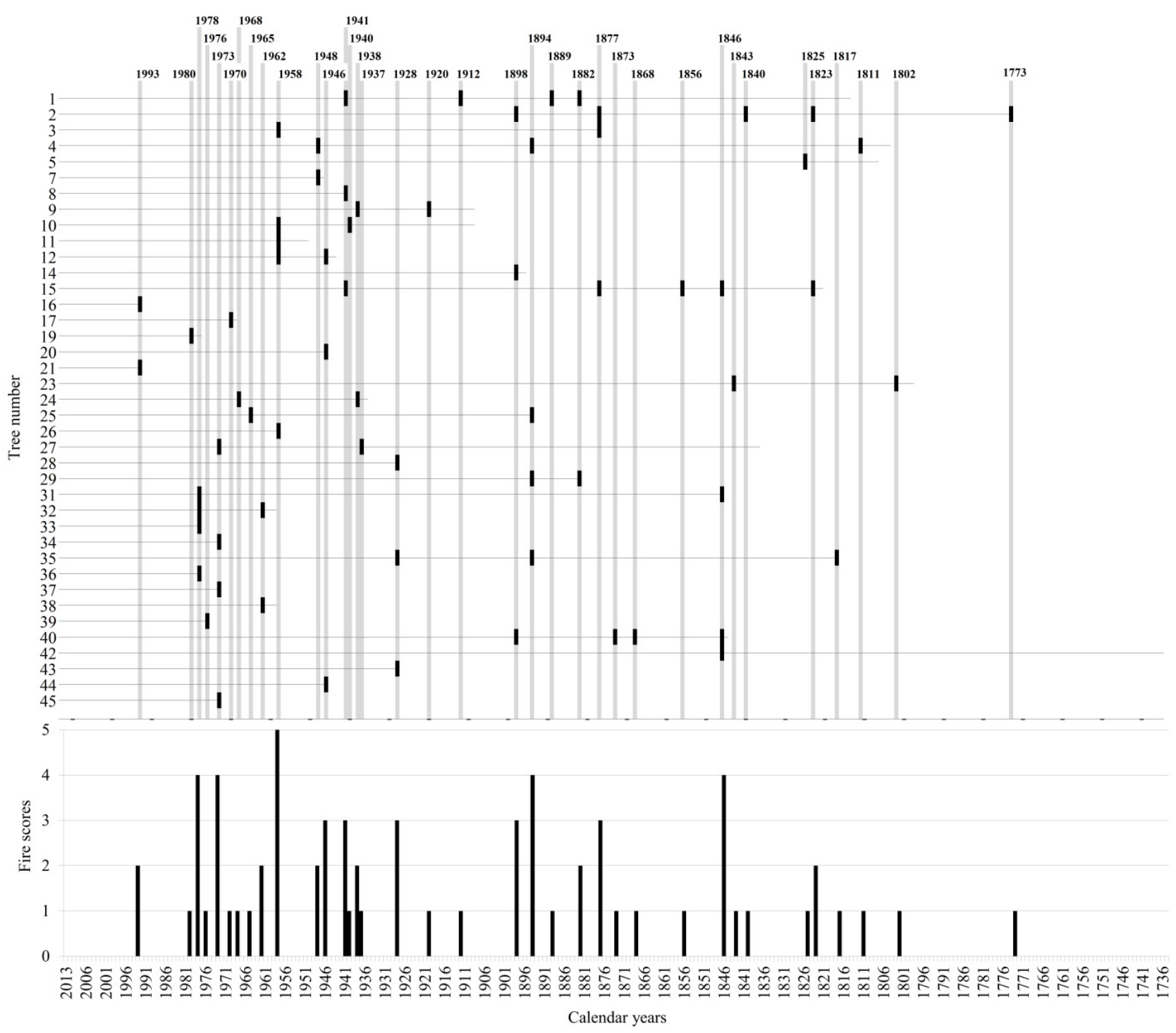

Fig. 11. Fire scar history data from the Bikin River based on Pinus koraiensis cores. Horizontal lines represent individual trees, on which years with the fire scars are marked with black vertical lines

\section{Discussion}

\section{Stratigraphy of charcoals in the soil}

Position of charcoals in the soil combined with morphological features of the charcoals is a powerful tool for reconstruction of a local fire history [30, 34-38, 58].

Charred stumps and deadwood as well as large charcoal pieces in the litter or on the border with mineral soil are an indication of relatively recent fires (most likely, ground fires). Large charcoal fragments with sharp edges and without masking by mineral soil testify quick or recent dumping of charcoal. Such charcoal fragments were typical in the litter (Fig. 12) and were found in the same areas as scared trees, so likely they originate from the fires that damaged the trees, which started from 1773. 


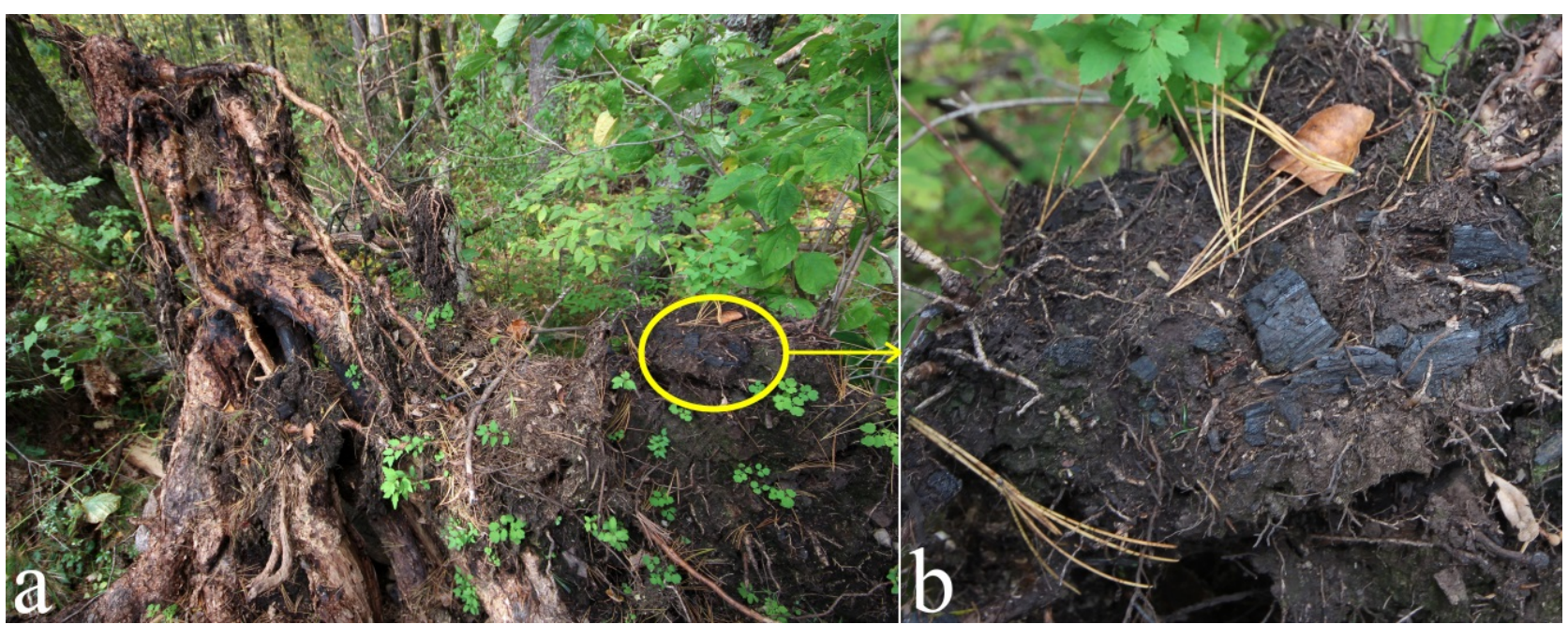

Fig. 12. Treefall mound (a) where charcoal is located in the litter (b)

In most of the treefall mounds, charcoals were found in the mineral soil at a distance from 10 to $50 \mathrm{~cm}$ below the ground surface of the soil (measured from the front wall of the mound). The presence of charcoal in the mineral soil may be due to the several processes transporting charcoal from the soil surface (where they lie after the fire) into the mineral horizons. Such processes can be pedoturbation, soil creep, or sedimentary process associated with slope erosion.

The leading role of treefall pedoturbations in charcoal dumping in forest soils has been reported in previous studies [59-65]. Soil charcoals associated with windfalls have been studied, for example by Gavin [60], Embleton-Hamann [66], Talon et al. [61], Šamonil et al. [67], Bobrovsky et al. [68], etc. In the gravelly brown soils of the study area, the depth of pits after treefall varies mainly between 0,4 and $1 \mathrm{~m}$, and rotation treefalls (see [65, 69] for definitions) prevail. In this type of treefalls, a tree trunk rotates and slides back into the pit formed after tree uprooting; at it happens, charcoals usually move deep into the pit and form clusters. In the study area, we found charcoal layers or clusters in more than half of the examined treefall mounds. The charcoals were mostly with clear edges, with the surface in various degrees masked by mineral particles. It means that charcoal dumping was fast that happens when charcoals are buried by treefalls with uprooting. Sometimes charcoals were found in mounds of treefall deeper than large stones (Fig. 13). We propose that such stones were dislocated in loose material of the upper soil horizon by past treefalls too.

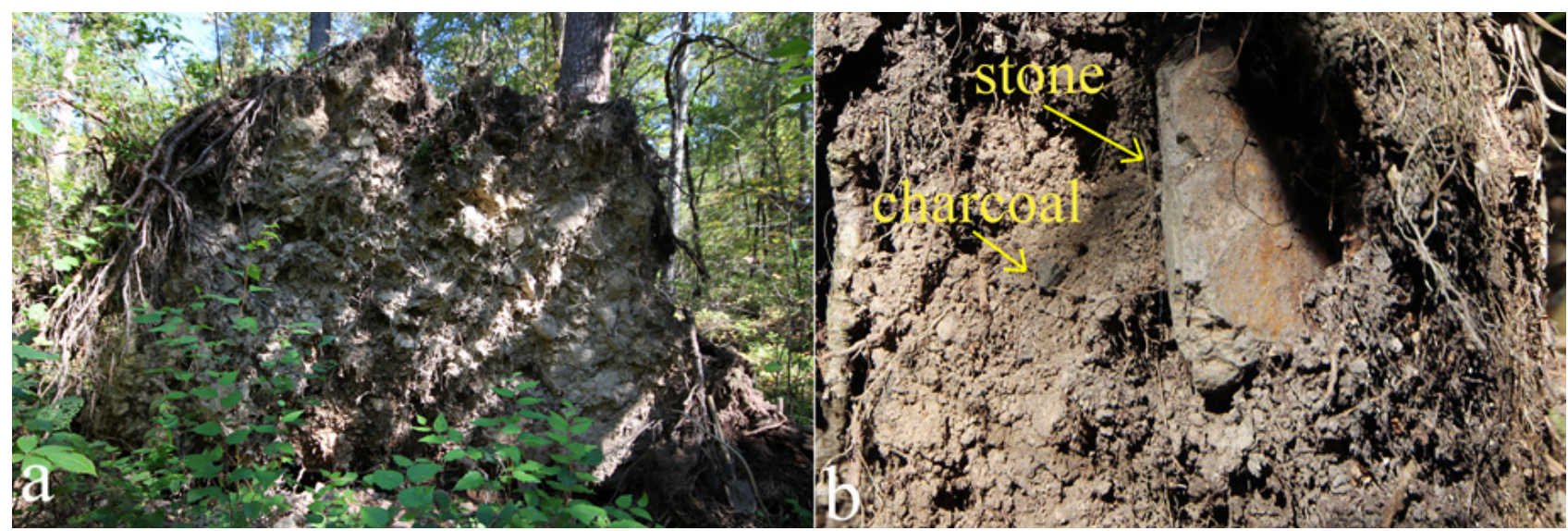

Fig. 13. Treefall mound ( $a$ ) with charcoal located deeper than a stone (b); soil surface is situated on the right in the figure (b). Charcoal is the sample No 7, $3720 \pm 113 \mathrm{cal} \mathrm{BP}$

Along with the treefalls with uprooting, soil creep is widespread in the study region, which also can be an important agent of pedoturbation. Soil creep is caused by high seasonal humidity that causes water saturation of the soil on the slopes, combined with high seasonal fluctuations of soil temperature and humidity [70]. The key sign for the presence of soil creep is tree trunk deformations. In our study area, deformations of tree trunks were absent in the areas with treefalls with uprooting; evidence of creeps was observed on steeper slopes outside the studied area. Potentially, 
soil creep plays only a local role in the study area, participating in the small-scale moving of the soil to pits formed by treefalls, which might be hard to detect $[71,72]$.

Slope erosion is widespread and is an important factor of the soil formation in the mountains of Primorye [10]. On the whole, erosion intensity depends on precipitation sum per a time unit (intensity) and slope steepness [73, 74]. Significant part of charcoal can be transported by rain waters [28, 75-78]. Fires increase the intensity of erosion [79-82]: as a result of fire, the natural water repellence of soil often increases because of the formation of a continuous water-repellent layer a few $\mathrm{cm}$ beneath the surface; it implies limitations in soil permeability and, thus, increased runoff and erosion [80, 83]. Additionally, fires cause a loss of soil connectivity as a result of organic matter burning [84] and damage the vegetation and litter that naturally serve as a soil protective screen against erosion [85]. Thus, in the mountains, soil erosion is an important fac- tor of charcoal transportation and dumping inside the mineral soil though within-hilloscope deposition is not well investigated till now [86] in contrary to a formation of sediments in the low part of slopes which are better investigated [87-89].

Usually middle parts of slopes are relatively flat in the study area; these zones contain accumulations of graves, larger stones, and creeped mineral soil which shift from the more elevated and steeper parts of the slopes. Most of the charcoals we found in treefall mounds there had mostly a disperse distribution, were semi-rounded and localized in soils with signs of erosion, such as weak connectivity and existence of light material. All these features indicate that these charcoals were buried in soil by slope processes (Fig. 14). Thus, in the study area, past pedoturbations by treefalls with uprooting and slope erosion are the main processes led to transport of charcoal into the mineral soil, which is now is exposed for studies by mounds of more recent treefalls.

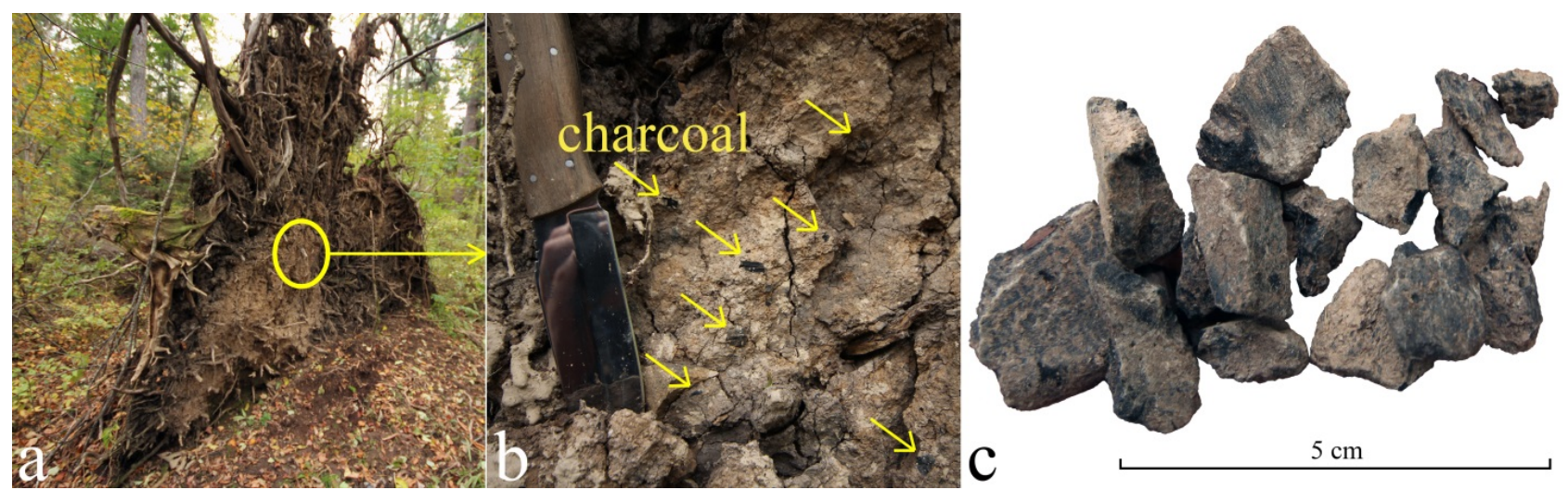

Fig. 14. Treefall mound (a), charcoal in the back wall of this mound, and rounded charcoal pieces extracted from the soil (b); sample No 13, $1340 \pm 40$ cal BP

\section{Charcoals spatial placement and age of soil charcoals}

There are previously dated charcoals from sediments sampled in four sites located in the floodplain and in the terraces of the middle reaches of the Bikin River [19-23]. According to charcoals, the oldest fires were dated to $30140 \mathrm{cal} \mathrm{BP}$ in the Sakhalin Mar; 13860 cal BP in the Kayalu section; 3965 cal BP in the Dillalakchi Bog; and 3610 cal BP in the Krasnyi Yar Bog [19-23]. Thus, previous studies have shown that fires are an ancient factor of landscape dynamics in the region. We were able to compare our results on soil charcoal dating with the previously reconstructed fire history, mostly focusing the comparison with the Krasnyi Yar Bog [20], which had the highest temporal resolution. This allowed us to test whether fires in our study area were synchronous to the previously reported fires as from the Bikin River basin as from the neighboring regions [91-94], to see if the entire region shared common fire history.

In our research, the most ancient dates (samples Nos 7 and 8) belong to the Upper Neolithic: $3720 \pm 113$ and $3247 \pm 93$ cal BP. These samples were found not far from each other in the northern part of the study area in the middle part of a slope (Fig. 15). Their dates are synchronous to the period of intensification of fires of 3765-2810 cal BP which was identified in the study of bogs [20]. These earliest fires are also synchronous to the period of increase in the fire frequency in the east of China. In China, this period of frequent fires was likely associated with continuous development of new cultivation tools and techniques between 4700 and 3300 (3100) yr BP, especially in time of the pre-Zhou Dynasty (early Predinastic Zhou) [91, 92]. Approximately at the same time $(3023 \pm 142$ cal BP, $2860 \pm 107 \mathrm{cal} \mathrm{BP}$ ), strong fires occurred in about $220 \mathrm{~km}$ to the north-east from the place of our re- 
search [93]. These fires covered a large area in the middle reaches of the Samarga River in the eastern macroslope of the Sikhote-Alin mountain range currently covered with dark coniferous taiga forests: the layer of charcoal was traced in the section of the floodplain terrace there for about $10 \mathrm{~km}$. These extensive fires might have caused a strong change in local vegetation. Thus, the Upper Neolithic fires in the studied area were synchronous to the surrounding regions.

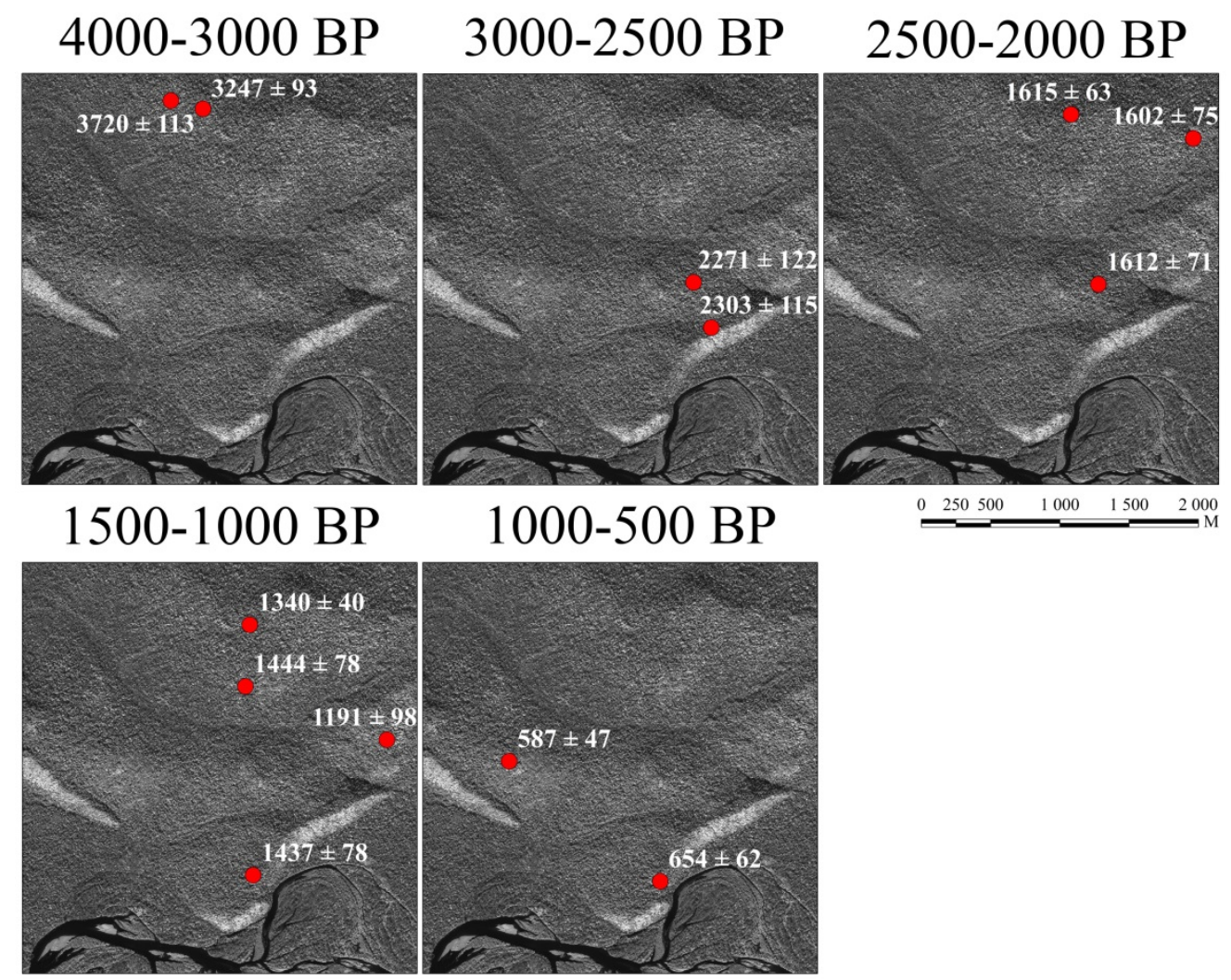

Fig. 15. Spatial placement of charcoal with different radiocarbon dates (cal BP)

The next cluster of our dates (about $2250 \mathrm{cal}$ BP) falls on the early Iron Age or on the Paleometal Era allocated for Primorye: $2303 \pm 115,2271 \pm$ $122,2210 \pm 89$ cal BP (samples Nos 22, 26 and 29). Two of them were found not far from each other, in the upper part of the slope (see Fig. 14) and the third one was outside the fragment of the image (in the west), also in the upper part of the slope. This time is also synchronous to the fire peak in China in 2210 (2250) cal BP [91]. At the Krasnyi Yar bog, a wider fire period around the same time was recorded, from 2590 to 1936 cal BP [20]. Finally, the dates $1955 \pm 20 \mathrm{cal} \mathrm{BP}$ and $2090 \pm 25 \mathrm{cal} \mathrm{BP}$ have been obtained for soil charcoal in another tract of Korean pine-deciduous forests in the Verkhneussyriysky Research Station on the western macroslope of the Sikhote-Alin Mountains, in about $320 \mathrm{~km}$ to southeast from our study area [94].

According to the bog studies, the next very long period of pyrogenic factor enhancement is about 1718-1062 cal BP [20]. In our study area, this period corresponds to seven dates from $1615 \pm 63$ to $1191 \pm 98$ cal BP. Within this period one can conditionally distinguish two more dense clusters: about 1610 cal BP (the boundary between Late
Iron and the Middle Ages, samples Nos 14, 15, and 23) and about $1450 \mathrm{cal}$ BP (the Middle Ages, samples Nos 4, 13, and 24; sample No 19 is also close to them). Charcoals of this time are relatively scattered over the area; they are found both in the upper and in the middle parts of the slope. Cluster of $1450 \mathrm{cal}$ BP intersects with the time of existence of the Bohai Kingdom, belonging to which the Kanchuga settlement was found in the study region [48]. For our study area, only from this time it is possible to associate the fire regime with human presence with some certainty until additional data on human history in the region will be obtained.

The last cluster of charcoal dates is about 600 cal BP: samples Nos 5 and 31, 654 \pm 62 and $587 \pm$ $47 \mathrm{cal}$ BP. It is a period of "dark history" in the region. For this time, there is no fire peak according to the peat data. However, for the time interval of 690-570 cal BP, Razzhigaeva et al. [20] noted a decrease in the participation of broad-leaved trees and the beginning of an increase in the share of the small-leaved trees of genera of Betula and Populus. Fires could be a cause of such a process.

Thus, our results demonstrate that the main periods of frequent fires in the middle reaches of the 
Bikin River were synchronous with fires recorded in adjacent areas using different methods up until to the Modern period.

\section{Fire scars on tree cores}

We further employed dendrochronological data to track the fire history in the area during the last centuries. The age of the oldest Korean pine individuals in our study area falls within the time period of a sharp increase in the proportion of Pinus koraiensis among the vegetation in the middle reaches of the Bikin River, which occurred between 1771 and 1820 [20].

Despite the small number of trees with fire scars found, we can confidently speak of periodic ground fires in the study area during the Modern Period. Even with possible inaccuracies in dating, the frequency of fires was no less than once every twenty years. For comparison, according to A. M. Starodumov [95], in the forests closed to valleys of the Amur, Gorin, and Hungari rivers, for the period from 1721 to 1948, severe fires occurred on average once in 15 years. As shown by the analysis of Korean pine trunks there, up to 30 depressions of growth happened every 50 years as a result of fires.

It is difficult to tie the fire regime in the middle reaches of the Bikin River with some well-known events including human activities until the end of the 19th century reliably. At the beginning of the 20th century, the Bikin River basin was inhabited by aboriginal tribes, and the Chinese population was also present. On the map of the Bikin basin (Fig. 1, [40]), one can see Orochi villages not far from the study area (V. Arsenyev mentioned them in 1908), as well as Chinese huts (fanzes). Most likely, a similar situation was here also before the beginning of the Russian colonization. The aboriginal tribes might have strongly affected the fire regime of the area. Many authors point to the regularity and even inevitability of fires associated with the activities of hunter-gatherer tribes, though this topic remains not entirely understood [3, 9698]. Many authors have noted an active use of fire by the aboriginal population of Primorye $[6,9,13$, 95]. For example, according to the stories of old residents, B. P. Kolesnikov [8] described the practice when aboriginal people deliberately set fire to the taiga to attract ungulates (elk, red deer). Birch and aspen are renewed on young burns, the abundance of grasses, which are attractive food for ungulates, is increasing. Taiga was also burned during tribal military conflicts. Until 1900, fires were markedly confined to the tracks - the path from the floodplain of the Bikin River on the Ulm Mound and the path along the ridge of the hill (Fig. 16). The fire of 1884 coincides with the documented time of the beginning of logging on the Bikin River for the construction of the railway.

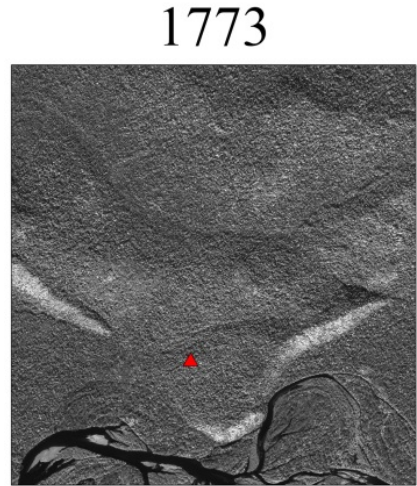

1912-1928

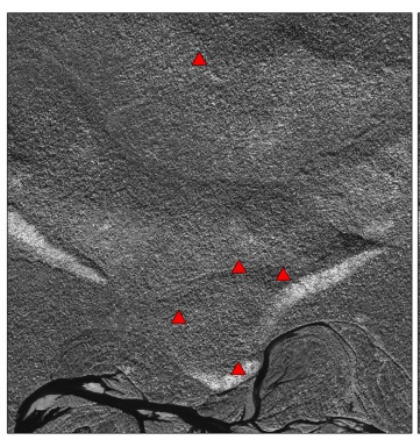

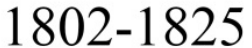

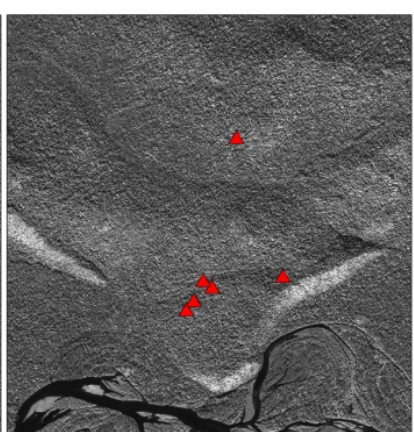

$1937-1948$

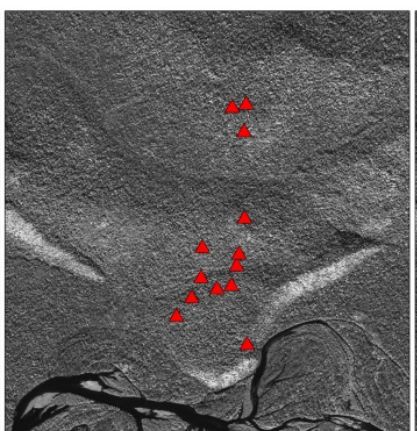

$1840-1856$

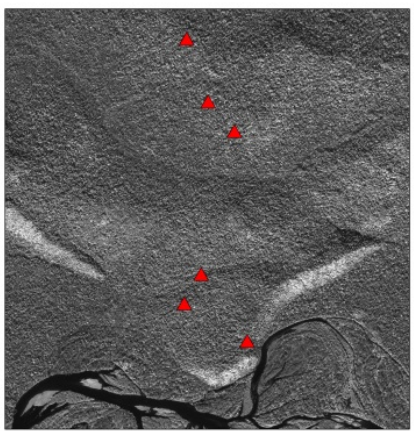

$1958-1980$

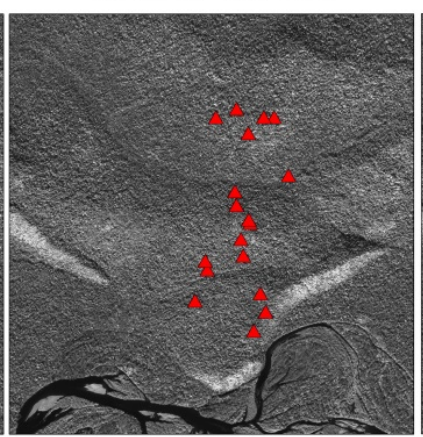

$1868-1898$

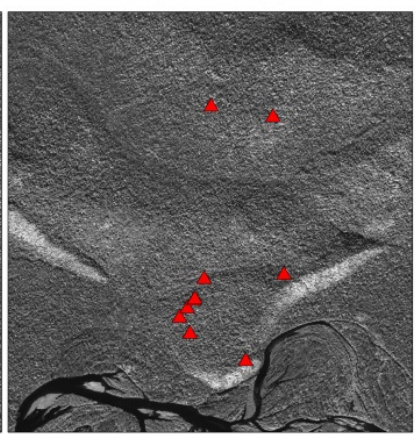

1993

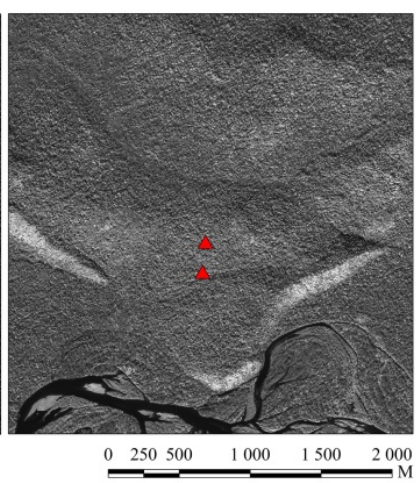

Fig. 16. Location of the studied Pinus koraiensis individuals with fire scars of different time 
One would expect a sharp increase in the frequency of fires since the Russian colonization. On the whole, according to numerous testimonies, the Russian colonization of Primorsky Krai in the late 19th and early 20th centuries was accompanied by massive fires. Fires were used in clearing land for settlements, arable land, and hayfields. The Chinese, forced out by the Russians, set fire to their fanzes and the forest before their leaving [8]. Most of the fires were in the most actively populated areas: in the south of Primorye and along the Pacific coast. In 1885, M. I. Pyastushkevich [6] wrote of fires as a global disaster. However, for the study area, we did not mark an increase in fires for the time when the forest plant in the Bikin River began operations (from 1905), when the Old Believers settled in the Bikin River valley (1918-1920), and when the construction of the village Metakheza upstream of the research site began (1934-1936).

A marked increase in the fire frequency occurred from 1937-1938. It can be directly related to the spread of logging, and coincides with a commencement of a logging station in the village of Verkhniy Pereval. In the study area, traces of old logging, such as stumps, including those that served as a substrate for the regeneration of trees, are very common (Fig. 17). Potentially, these might be the result of selective logging of Pinus koraiensis in the Amba River basin in the late 1930s and in the 1940s. Old stumps are often adjacent to the trunks of Pinus koraiensis with fire scars.

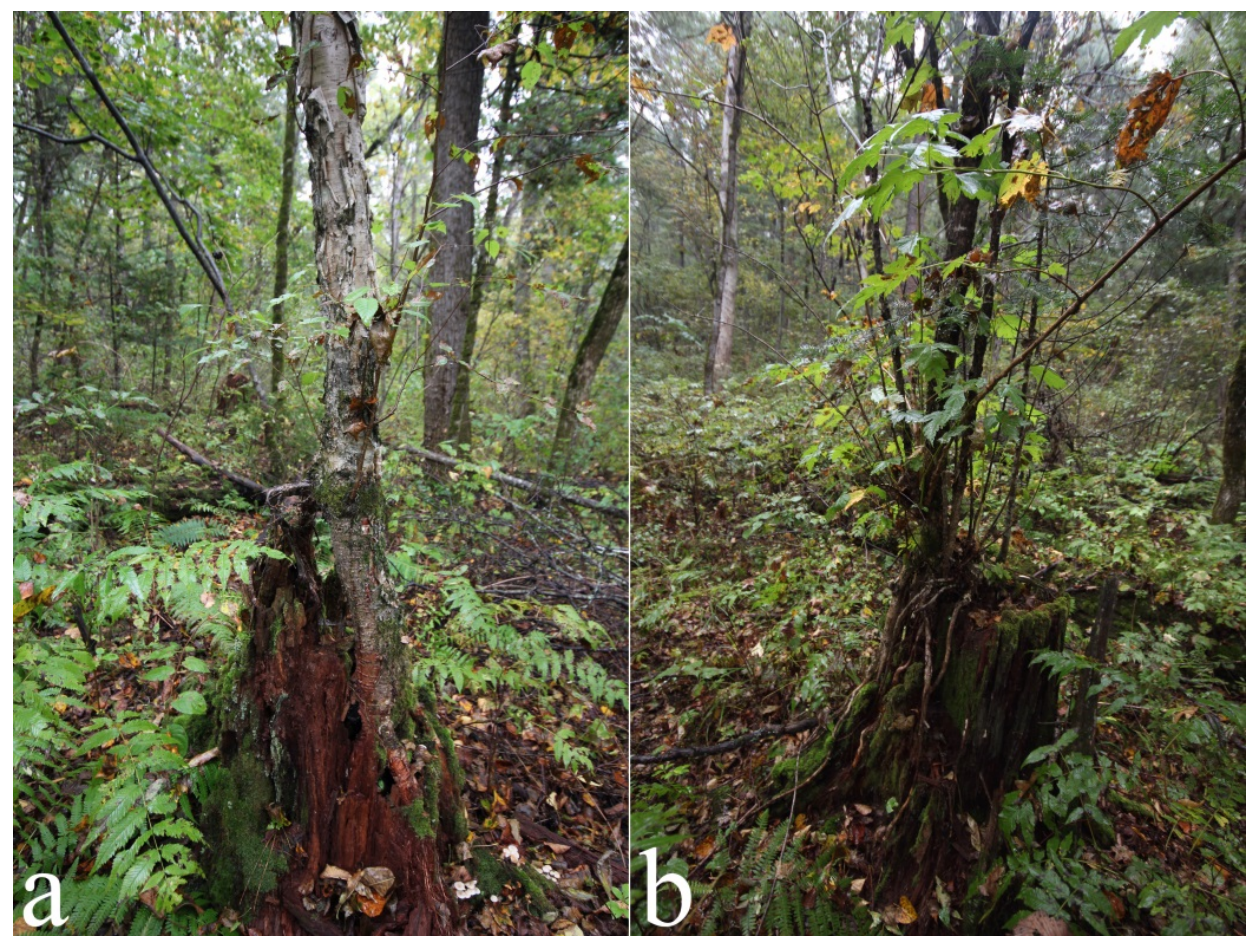

Fig. 17. Betula costata (a) и Acer ukurunduense (b) on old stumps of Pinus koraiensis in the Ulma Mound, the middle reaches of the Bikin River

From 1948 to 1957 there were no traces of fires, and the next period of fires with a high frequency is from 1958 to 1980 . The largest number of fire scores during this time was in 1958 and 1976. This is the time when active logging on the lower reaches of the Bikin River began again, and felling of the forest near the study area started in the late 1960s. Creating a cedar-nut-production zone and the prohibition of logging in 1971 [50] did not lead to the cessation of fires immediately.

Fire points in 1937-1948 and 1958-1980 time intervals form a "dense" belt in the middle part of the western slope (see Fig. 16). It is difficult to estimate the area and intensity of these fires. We assume that in the area from the Bikin River to the second tributary north of the Bikin River, ground fire areas could be significant. In contrast, in the northern part of the study area, areas of ground fires were relatively small (possibly, at sites of burning logging residues or other forestry activity), based, in particular, on the fact that fire scars are found here mainly on small-diameter Pinus koraiensis trunks, but not on the trunks of larger trees next to them. From 1960 to 1970, the number of fires on the top of the Ulma Mound increased; the charred deadwood of Pinus koraiensis, charcoal in the litter (see above) was also found there. After 1980, there was only one fire in 1993. Probably the main cause of such a significant reduction in fires is the cessation of logging in the study region, and the overall decline in human population. 
Many authors note that human activity was the main cause of fires in Primorye, while the climate primarily controls the spreading area of fires $[13,99]$. We compared our data on the number of fire scars with the data on the Sikhote-Alin State Nature Reserve which is located $150-200 \mathrm{~km}$ south of the study area, mainly on the eastern macro slope of the Sikhote-Alin Mountains (Table 2). The years with fires often coincide with years with low precipitation or the years following them. The years with fires in the middle reaches of the Bikin River sometimes coincide, and sometimes do not coincide with the years of large fires in the Reserve. As expected, there were no coincidences of fires over the years with high rainfall.

Table 2

Years with high and low levels of precipitations and different number of fires in the Sikhote-Alin State Nature Reserve and in the study area

\begin{tabular}{|c|c|c|c|c|}
\hline \multirow{2}{*}{ Year } & \multicolumn{3}{|c|}{ Data on Sikhote-Alin State Nature Reserve (from [13]) } & \multirow{2}{*}{$\begin{array}{l}\text { The middle reaches } \\
\text { of the Bikin River } \\
\text { Number of fire scores }\end{array}$} \\
\hline & $\begin{array}{c}\text { High level } \\
\text { of precipitations }\end{array}$ & $\begin{array}{c}\text { Low level } \\
\text { of precipitations }\end{array}$ & $\begin{array}{l}\text { Large number } \\
\text { of fires }\end{array}$ & \\
\hline 1957 & & + & & \\
\hline 1958 & & + & + & 5 \\
\hline 1959 & + & & & \\
\hline 1965 & & & & 1 \\
\hline 1968 & & & & 1 \\
\hline 1969 & + & & & \\
\hline 1970 & & & & 1 \\
\hline 1971 & + & & & \\
\hline 1973 & & + & & 4 \\
\hline 1974 & + & & & \\
\hline 1975 & & + & & \\
\hline 1976 & & & & 1 \\
\hline 1977 & & + & + & \\
\hline 1978 & & & + & 4 \\
\hline 1980 & & & & 1 \\
\hline 1982 & & + & + & \\
\hline 1984 & + & & & \\
\hline 1986 & & + & & \\
\hline 1987 & & + & & \\
\hline 1989 & & & + & \\
\hline 1992 & & + & & \\
\hline 1993 & & & + & 2 \\
\hline 1994 & + & & & \\
\hline 1997 & & + & + & \\
\hline 1998 & & & + & \\
\hline 1999 & & & + & \\
\hline 2003 & & + & & \\
\hline 2006 & & & + & \\
\hline
\end{tabular}

There is currently not enough data to estimate what role fires played in the formation of modern Korean pine-broadleaved forests, as the fire history of these forests in the Sikhote-Alin Mountains was very variable. The results of our research show a significant number of forest fires in the study area in the middle reaches of the Bikin River during the last millennia. But at the same time, results of a study of intact Korean pine-broadleaved forests in the area of the Verkhneussyriysky Research Station based on dendrochronological and pedoanthracological data showed the last fires of about 2000 cal BP $[94,100]$.
Despite the large number of fires, a high species diversity of plants, primarily woody ones, was maintained in the study area: there were not principal changes in the woody species composition during the last three thousand years [19-21]. Species conservation can be explained by the relatively local spread of fires along with the presence of fire refugia. The main and permanent refugium is probably the floodplain of the Bikin River; also areas of the "fire shade" under protection of rocky outcrops can serve as fire havens. Razzhigaeva et al. [20] pointed out the role of strong microclimatic variability, which is caused by the complex relief, 
in the preservation of flora under the climate change in the study region. The strong microclimatic variability could also protect vegetation in the area from fire.

\section{Conclusion}

Numerous researches have shown relationships between fire regimes and colonization history, and anthropogenic impacts in general, for diverse cultural subsistence traditions and land use practices $[101,102]$. At the same time, it is not well known to what extent hunter-gatherers and farming societies influenced fire regimes and landscapes $[3,97,98,103]$. Such knowledge is also scarce for the region of the Sykhote-Alin Mountains.

The study region has a long fire history and periods with an increased frequency of fires are distinguished [19, 20, 22, 23, 104]. Our investigation confirmed the results of the previous studies and on the basis of dendrochronological and perdoanthracological data firstly showed that fires oc- curred on the slopes of the Ulm Mound inside the stands of the Korean pine-broadleaved forests. Soil charcoals were dated from 3720 to $587 \mathrm{cal} \mathrm{BP}$; the data on fire scars presented a fairly intense fire history during the last 240 years. Until the end of the first millennium (time of the Bohai Kingdom existence) there are no archaeological or other data confirming the existence of economy in the study area that would allow us to associate the frequency of fires with specific human activities. For the Modern period, rather high fire frequency was identified. Remarkable increase of fire frequency has coincided with periods of forest logging since the end of the 19th century.

\section{Acknowledgements}

I am grateful to A. Puryakhovsky, A. Omelko and $\mathrm{O}$. Ukhvatkina for organizing the field expedition. This research was carried out within the framework of the Basic Scientific Research theme (Reg. No. AAAA-A18-118013190176-2).

\section{Библиографический список}

1. Global wildland fire season severity in the 21 st century / M. Flannigan, A. S. Cantin, W. J. De Groot, M. Wotton, A. Newbery, L. M. Gowman // Forest Ecology and Management. - 2013. - Vol. 294. - P. 54-61.

2. Learning to coexist with wildfire / M. A. Moritz, E. Batllori, R. A. Bradstock, A. M. Gill, J. Handmer, P. F. Hessburg, J. Leonard, S. McCaffrey, D. C. Odion, T. Schoennagel, A. D. Syphard // Nature. - 2014. - Vol. 515 (7525). P. 58.

3. Global biomass burning: a synthesis and review of Holocene paleofire records and their controls / J. R. Marlon, P. J. Bartlein, A. L. Daniau, S. P. Harrison, S. Y. Maezumi, M. J. Power, W. Tinner, B. Vanniére // Quaternary Science Reviews. - 2013. - Vol. 65. - P. 5-25.

4. Whitlock, C. Paleoecological perspectives on fire ecology: revisiting the fire-regime concept / C. Whitlock, P. E. Higuera, D. B. McWethy, C. E. Briles // The Open Ecology Journal. - 2010. - Vol. 3 (1).

5. Пржевальский, Н. М. Путешествие в Уссурийском крае в 1867-1869 гг. / Н. М. Пржевальский. - СанктПетербург, 1870. - 348 с.

6. Леса Дальнего Востока глазами первопроходцев / сост. Ю. И. Манько, А. Ж. Пуреховский ; науч. ред. Ю. И. Манько. - Санкт-Петербург : Изд. Д. В. Львов, 2016. - 512 с.

7. Комаров, В. Л. Типы растительности Южно-Уссурийского края / В. Л. Комаров // Труды почвенноботанической экспедиции 1913 г. - 1917. - Вып. II. - 216 с.

8. Колесников, Б. П. Растительность восточных склонов Среднего Сихотэ-Алиня / Б. П. Колесников // Труды Сихотэ-Алиньского заповедника. - 1938. - Вып. 1. - С. 25-207.

9. Колесников, Б. П. Кедровые леса Дальнего Востока / Б. П. Колесников. - Москва ; Ленинград : Изд-во АН CCCP, 1956. $-261 \mathrm{c}$.

10. Колесников, Б. П. Растительность / Б. П. Колесников // Дальний Восток. - Москва : Изд-во АН СССР, 1961. - C. 183-298.

11. Шеметова, Н. С. Кедрово-широколиственные леса и их гари на восточных склонах Среднего СихотэАлиня / Н. С. Шеметова. - Владивосток, 1970. - 104 с.

12. Комарова, Т. А. Послепожарные сукцессии в лесах южного Сихотэ-Алиня / Т. А. Комарова. - Владивосток : Дальнаука, 1992. - 224 с.

13. Пожары и их влияние на природные экосистемы Центрального Сихотэ-Алиня / отв. ред.: Б. С. Петропавловский, А. А. Астафьев. - Владивосток : Дальнаука, 2010. - 264 с.

14. Короткий, А. М. Четвертичные отложения Приморья: Стратиграфия и палеогеография / А. М. Короткий, Л. П. Караулова, Т. С. Троицкая. - Новосибирск : Наука, 1980. - 234 с.

15. Голубева, Л. В. Растительность и климатостратиграфия плейстоцена и голоцена юга Дальнего Востока СССР / Л. В. Голубева, Л. П. Караулова. - Москва : Наука, 1983. - 143 с.

16. Короткий, А. М. Аномальные природные процессы и их влияние на состояние геосистем юга Российского Дальнего Востока / А. М. Короткий, В. В. Коробов, Г. П. Скрыльник. - Владивосток : Дальнаука, 2011. $265 \mathrm{c}$. 
17. Алешинская, 3. В. Миграция высотных поясов растительности среднего Сихотэ-Алиня в голоцене / 3. В. Алешинская, Н. С. Болиховская, В. Ф. Болиховский // Доклады АН СССР. - 1980. - Т. 254, № 4. C. 949-963.

18. Белянин, П. С. Развитие геосистем бассейна реки Бикин (Дальний Восток) в среднем и позднем голоцене / П. С. Белянин // География и природные ресурсы. - 2013. - № 1. - С. 105-111.

19. Палеоклиматическая и палеоландшафтная записи в голоценовых отложениях среднего течения реки Бикин (Приморье) / Н. Г. Разжигаева, Л. А. Ганзей, Т. А. Гребенникова, Л. М. Мохова, А. М. Паничев, Т. А. Копотева, Х. А. Арсланов, А. А. Старикова, В. В. Крупская, Ф. Е. Максимов // Тихоокеанская геология. 2016. - Т. 35, № 5. - С. 86-100.

20. Ретроспективный анализ изменчивости ландшафтов бассейна реки Бикин (среднее течение) / Н. Г. Разжигаева, Л. А. Ганзей, А. М. Паничев, Х. А. Арсланов, Л. М. Мохова, Т. А. Копотева, Е. П. Кудрявцева, Т. А. Гребенникова, Т. Р. Макарова, Ф. Е. Максимов, А. Ю. Петров // Biodiversity and Environment of Far East Reserves. - 2016. - № 1 (8). - С. 173-210.

21. Реакция ландшафтов западного макросклона Сихотэ-Алиня на климатические изменения в среднемпозднем голоцене / Н. Г. Разжигаева, Л. А. Ганзей, А. М. Паничев, Т. А. Гребенникова, Л. М. Мохова, Т. А. Копотева, Е. П. Кудрявцева, Х. А. Арсланов, Ф. Е. Максимов, А. А. Старикова, С. В. Закусин // Геофизические процессы и биосфера. - 2016. - Т. 15, № 3. - С. 35-66.

22. Этапы развития ландшафтов западного макросклона Сихотэ-Алиня на рубеже плейстоцена-голоцена (бассейн реки Бикин) / Н. Г. Разжигаева, Л. А. Ганзей, Л. М. Мохова, Т. А. Гребенникова, А. М. Паничев, Т. А. Копотева, Е. П. Кудрявцева, Х. А. Арсланов, Ф. Е. Максимов, А. А. Старикова, А. Ю. Петров // География и природные ресурсы. - 2017. - № 3. - С. 127-138.

23. Этапы развития ландшафтов предгорий западного Сихотэ-Алиня / Н. Г. Разжигаева, Л. А. Ганзей, Л. М. Мохова, Т. Р. Макарова, А. М. Паничев, Т. А. Копотева, Е. П. Кудрявцева, Х. А. Арсланов, Ф. Е. Максимов, А. Ю. Петров, В. В. Крупская // Известия Российской академии наук. Серия географическая. - 2017. № 4. - C. 97-111.

24. Lehtonen, H. Influence of man on forest fire frequency in North Karelia, Finland, as evidenced by fire scars on Scots pines / H. Lehtonen, P. Huttunen, P. Zetterberg // Annales Botanici Fennici. - 1996. - Vol. 33. - P. $257-263$.

25. Niklasson, M. A 600-year tree-ring fire history from Norra Kvills National Park, southern Sweden: implications for conservation strategies in the hemiboreal zone / M. Niklasson, B. Drakenberg // Biological Conservation. 2001. - Vol. 101 (1). - P. 63-71.

26. Reconstructing past fire regimes: methods, applications, and relevance to fire management and conservation / M. Conedera, W. Tinner, C. Neff, M. Meurer, A. F. Dickens, P. Krebs // Quaternary Science Reviews. - 2009. Vol. 28 (5-6). - P. 555-576.

27. Wave of fire: an anthropogenic signal in historical fire regimes across central Pennsylvania, USA / M. S. Stambaugh, J. M. Marschall, E. R. Abadir, B. C. Jones, P. H. Brose, D. C. Dey, P. R. Guyette // Ecosphere. - 2018. Vol. $9(5)$.

28. Clark, J. S. Particle motion and the theory of stratigraphic charcoal analysis: source area, transportation, deposition, and sampling / J. S. Clark // Quaternary Research. - 1988. - Vol. 30. - P. 81-91.

29. Clark, J. S. Relationships between charcoal particles in air and sediments in westcentral Siberia / J. S. Clark, J. Lynch, B. J. Stocks // Holocene. - 1998. - Vol. 8. - P. 19-29.

30. Carcaillet, C. Pedoanthracological contribution to the study of the evolution of the upper treeline in the Maurienne Valley (North French Alps): methodology and preliminary data / C. Carcaillet, M. Thinon // Rev. Palaeobot. Palynol. - 1996. - Vol. 91 (1-4). - P. 399-416.

31. Ohlson, M. Interpretation of the charcoal record in forest soils: forest fires and their production and deposition of macroscopic charcoal / M. Ohlson, E. Tryterud // Holocene. - 2000. - Vol. 10 (4). - P. 519-525.

32. Long-distance transport of macroscopic charcoal by an intensive crown fire in the Swiss Alps-implications for fire history reconstruction / W. Tinner, S. Hofstetter, F. Zeugin, M. Conedera, T. Wohlgemuth, L. Zimmermann, R. Zweifel // Holocene. - 2006. - Vol. 16 (2). - P. 287-292.

33. Talon, B. Reconstruction of Holocene high-altitude vegetation cover in the French southern Alps: evidence from soil charcoal / B. Talon // Holocene. - 2010. - Vol. 20 (1). - P. 35-44.

34. Touflan, P. Soil charcoal analysis: a reliable tool for spatially precise studies of past forest dynamics: a case study in the French southern Alps / P. Touflan, B. Talon, K. Walsh // Holocene. - 2010. - Vol. 20 (1). - P. 45-52.

35. The charcoal carbon pool in boreal forest soils / M. Ohlson, B. Dahlberg, T. Økland, K. J. Brown, R. Halvorsen // Nature Geoscience. - 2009. - Vol. 2 (10). - P. 692.

36. Nelle, O. Pedoanthracology: analysing soil charcoal to study Holocene palaeoenvironments / O. Nelle, V. Robin, B. Talon // Quat. Int. - 2013. - Vol. 289. - P. 1-4.

37. Robin, V. Contribution to the reconstruction of central European fire history, based on the soil charcoal analysis of study sites in northern and central Germany / V. Robin, O. Nelle // Veg. Hist. Archaeobotany. - 2014. - Vol. 23 (1). P. 51-65.

38. Late-Holocene fire history as revealed by size, age and composition of the soil charcoal pool in neighbouring beech and spruce forest landscapes in SE Norway / M. Ohlson, V. M. Ellingsen, M. V. del Olmo, M. H. Lie, L. Nybakken, J. Asplund // Holocene. - 2017. - Vol. 27 (3). - P. 397-403.

39. Бочарников, В. Н. Национальный парк «Бикин» / В. Н. Бочарников, Ю. Н. Глущенко, К. Е. Михайлов, Е. Г. Егидарев // Biodiversity and Environment of Far East Reserves. - 2016. - № 1 (8). - С. 3-24. 
40. Bikin. NL53-5. List from Eastern Siberia AMS Topographic Maps. Series N504, U.S. Army Map Service, 1950. A Univercity of Texas libraries. - URL: http://legacy.lib.utexas.edu/maps/ams/eastern_siberia/txu-oclc-6572926n153-5.jpg (accessed at 11.12.2018).

41. Экосистемы бассейна р. Бикин: среда, человек, управление. - Владивосток : ДВО РАН, 1997. - 176 с.

42. Атлас лесов Приморского края. - Владивосток : ДВО РАН, 2005. - 76 с.

43. Криштофович, А. Н. Эволюция растительного покрова в геологическом прошлом и ее основные факторы / А. Н. Криштофович // Материалы по истории флоры и растительности СССР. - Москва ; Ленинград : Издво АН СССР, 1946. - Вып. II. - С. 21-87.

44. Krestov, P. V. Forest vegetation for Easternmost Russia (Russian Far East) / P. V. Krestov // For. Veg. Northeast Asia. - Dordrecht, 2003. - P. 93-180.

45. Список выявленных объектов археологического наследия, расположенных на территории Хабаровского края, по состоянию на 1 января 2015 года (Приказ Министерства культуры Хабаровского края от 23.10.2015). - URL: https://pandia.ru/text/80/032/2700.php (accessed at 11.12.2018).

46. Атлас Приморского края / ред.: Е. Н. Наздратенко, Н. М. Цымбаленко. - Владивосток : ДВ АГП, 1998.

47. Дьякова, О. В. Государство Бохай: археология, история, политика / О. В. Дьякова. - Москва : Наука ; Вост. лит., 2014. -318 c.

48. China Handbook Editorial Committee // China Handbook Series: History : trans. by Dun J. Li. - Beijing, 1982. P. 89-188.

49. Паничев, А. М. Бикин. Тайга и люди / А. М. Паничев. - Владивосток : Изд-во ДВГТУ, 2005. - 250 с.

50. Шибнев, Б. К. Живой Бикин. Неравнодушные записки: рассказы, очерки, статьи / Б. К. Шибнев. - Владивосток : АВК «Апельсин», 2006. - 329 с.

51. IntCal13 and Marine13 radiocarbon age calibration curves, 0-50,000 Years cal BP / P. J. Reimer, E. Bard, A. Bayliss, J. W. Beck, P. G. Blackwell, C. Bronk Ramsey, C. E. Buck, H. Cheng, R. L. Edwards, M. Friedrich, P. M. Grootes, T. P. Guilderson, H. Haflidason, I. Hajdas, C. Hatté, T. J. Heaton, D. L. Hoffmann, A. G. Hogg, K. A. Hughen, K. F. Kaiser, B. Kromer, S. W. Manning, M. Niu, W. Reimer, D. A. Richards, E. M. Scott, J. R. Southon, R. A. Staff, C. S. M. Turney, J. van der Plicht// Radiocarbon. - 2013. - Vol. 55. - P. $1869-1887$.

52. Arno, S. F. A method for determining fire history in coniferous forests of the Mountain West / S. F. Arno, K. M. Sneck // Gen. Tech. Rep. - 1977. - INT-42.

53. Zackrisson, O. Influence of forest fires on the north Swedish boreal forest / O. Zackrisson // Oikos. - 1977. Vol. 29. - P. 22-32.

54. Niklasson, M. Numbers and sizes of fires: long-term spatially explicit fire history in a Swedish boreal landscape / M. Niklasson, A. Granström // Ecology. - 2000. - Vol. 81. - P. 1484-1499.

55. Schulze, E. D. Succession after stand replacing disturbances by fire, wind throw, and insects in the dark Taiga of Central Siberia / E. D. Schulze, C. Wirth, D. Mollicone, W. Ziegler // Oecologia. - 2005. - Vol. 146 (1). - P. $77-88$.

56. Wallenius, T. Declining fires in Larix-dominated forests in northern Irkutsk district. International / T. Wallenius, M. Larjavaara, J. Heikkinen, O. Shibistova // Journal of Wildland Fire. - 2011. - Vol. 20 (2). - P. $248-254$.

57. Barrett, S. W. Increment-borer methods for determining fire history in coniferous forests / S. W. Barrett, S. F. Arno // Gen. Tech. Rep. - 1988. - Vol. 15. - P. 244.

58. Couillard, P. L. Comparative methods for reconstructing fire histories at the stand scale using charcoal records in peat and mineral soils / P. L. Couillard, J. Tremblay, M. Lavoie, S. Payette // Forest Ecology and Management. 2019. - Vol. 433. - P. 376-385.

59. Пономаренко, Е. В. Методические подходы к анализу сукцессионных процессов в почвенном покрове / Е. В. Пономаренко ; ред.: О. В. Смирнова, Е. С. Шапошников // Сукцессионные процессы в заповедниках России и проблемы сохранения биологического разнообразия. - Санкт-Петербург : РБО, 1999. - С. 34-57.

60. Gavin, D. G. Forest soil disturbance intervals inferred from soil charcoal radiocarbon dates / D. G. Gavin // Can. J. For. Res. - 2003. - Vol. 33 (12). - P. 2514-2518.

61. Gavin, D. G. Holocene fire history of a coastal temperate rain forest based on soil charcoal radiocarbon dates / D. G. Gavin, L. B. Brubaker, K. P. Lertzman // Ecology. - 2003. - Vol. 84 (1). - P. 186-201.

62. Talon, B. Reconstruction of the long-term fire history of an old-growth deciduous forest in Southern Québec, Canada, from charred wood in mineral soils / B. Talon, S. Payette, L. Filion, A. Delwaide // Quat. Res. - 2005. Vol. 64. - P. 36-43.

63. Sanborn, P. Soil and sedimentary charcoal evidence for Holocene forest fires in an inland temperate rainforest, east-central British Columbia, Canada / P. Sanborn, M. Geertsema, A. T. Jull, B. Hawkes // Holocene. - 2006. Vol. 16 (3). - P. 415-427.

64. Бобровский, М. В. Лесные почвы европейской России: биотические и антропогенные факторы формирования / М. В. Бобровский. - Москва : КМК, 2010. - 359 с.

65. Bobrovsky, M. Patterns of pedoturbation by tree uprooting in forest soils / M. Bobrovsky, S. Loyko // Russian Journal of Ecosystem Ecology. - 2016. - Vol. 1 (1). - P. 1-22.

66. Embleton-Hamann, C. Processes responsible for the development of a pit and mound microrelief / C. EmbletonHamann // Catena. - 2004. - Vol. 57. - P. 175-188.

67. Crossdating of disturbances by tree uprooting: can treethrow microtopography persist for 6000 years? / P. Šamonil, R. J. Schaetzl, M. Valtera, V. Golias, P. Baldrian, I. Vasickova, D. Adam, D. Janik, L. Hort // For. Ecol. Manag. - 2013. - Vol. 307. - P. 123-135. 
68. Bobrovsky, M. V. Anthracological and morphological analysis of soils for the reconstruction of the forest ecosystem history (Meshchera Lowlands, Russia) / M. V. Bobrovsky, D. A. Kupriaynov, L. G. Khanina // Quaternary International. - 2019. (in press).

69. Beatty, S. W. The variety of soil microsites created by tree falls / S. W. Beatty, E. L. Stone // Can. J. For. Res. 1986. - Vol. 16 (3). - P. 539-548.

70. Воскресенский, С. С. Динамическая геоморфология. Формирование склонов / С. С. Воскресенский. Москва : Изд-во МГУ, 1971. - 229 с.

71. Lutz, H. T. Movement of rocks by uprooting of forest trees / H. T. Lutz // J. Sci. - 1960. - № 10. - P. $752-756$.

72. Pawlik, Ł. Soil creep: the driving factors, evidence and significance for biogeomorphic and pedogenic domains and systems-a critical literature review / Ł. Pawlik, P. Šamonil // Earth-Science Reviews. - 2018. - Vol. 178. P. 257-278.

73. García-Ruiz, J. M. A meta-analysis of soil erosion rates across the world / J. M. García-Ruiz, S. Beguería, E. Nadal-Romero, J. C. González-Hidalgo, N. Lana-Renault, Y. Sanjuán // Geomorphology. - 2015. - Vol. 239. P. 160-173.

74. Short-term effects of post-fire salvage logging on runoff and soil erosion / M. C. Malvar, F. C. Silva, S. A. Prats, D. C. Vieira, C. O. Coelho, J. J. Keizer // Forest ecology and management. - 2017. - Vol. 400. - P. 555-567.

75. Blong, R. J. Fluvial transported charcoal gives erroneous $14 \mathrm{C}$ ages for recent deposits / R. J. Blong, R. Gillespie // Nature. - 1978. - Vol. 271. - P. 739-741.

76. Patterson, W. A. Microscopic charcoal as fossil indicator of fire / W. A. Patterson, K. J. Edwards, D. J. Maguire // Quat. Sci. Rev. - 1987. - Vol. 6. - P. 3-23.

77. Carcaillet, C. Sedimentary charcoal pattern in a karstic underground lake, Vercors massif, French Alps: implications for palaeo-fire history / C. Carcaillet, A. S. Perroux, A. Genries, Y. Perrette // Holocene. - 2007. - Vol. 17 (6). P. 845-850.

78. Scott, A. C. Charcoal recognition, taphonomy and uses in palaeoenvironmental analysis / A. C. Scott // Palaeogeography, Palaeoclimatology, Palaeoecology. - 2010. - Vol. 291. - P. 11-39.

79. Lavee, H. Effect of surface roughness on runoff and erosion in a Mediterranean ecosystem: the role of fire / H. Lavee, P. Kutiel, M. Segev, Y. Benyamini // Geomorphology. - 1995. - Vol. 11 (3). - P. 227-234.

80. Certini, G. Effects of fire on properties of forest soils: a review / G. Certini // Oecologia. - 2005. - Vol. 143 (1). P. $1-10$

81. Shakesby, R. A. Wildfire as a hydrological and geomorphological agent / R. A. Shakesby, S. H. Doerr // EarthScience Reviews. - 2006. - Vol. 74 (3-4). - P. 269-307.

82. Fire effects on soil aggregation: a review / J. Mataix-Solera, A. Cerdā, V. Arcenegui, A. Jordán, L. M. Zavala // Earth-Science Reviews. - 2011. - Vol. 109 (1-2). - P. 44-60.

83. DeBano, L. F. The role of fire and soil heating on water repellency in wildland environments: a review / L. F. DeBano // Journal of hydrology. - 2000. - Vol. 231. - P. 195-206.

84. Wondzell, S. M. Postfire erosional processes in the Pacific Northwest and Rocky Mountain regions / S. M. Wondzell, J. G. King // Forest Ecology and Management. - 2003. - Vol. 178. - P. 75-87.

85. Johansen, M. P. Post-fire runoff and erosion from rainfall simulation: contrasting forests with shrublands and grasslands / M. P. Johansen, T. E. Hakonson, D. D. Breshears // Hydrological processes. - 2001. - Vol. 15 (15). P. 2953-2965.

86. Towards a global assessment of pyrogenic carbon from vegetation fires / C. Santin, S. H. Doerr, E. S. Kane, C. A. Masiello, M. Ohlson, J. M. de la Rosa, C. M. Preston, T. Dittmar // Global Change Biology. - 2016. Vol. 22 (1). - P. 76-91.

87. The influence of historic land-use changes on hillslope erosion and sediment redistribution / A. Larsen, V. Robin, T. Heckmann, A. Fülling, J. C. Larsen, H. R. Bork // Holocene. - 2016. - Vol. 26 (8). - P. 1248-1261.

88. Archaeopedology and chronostratigraphy of colluvial deposits as a proxy for regional land use history (Baar, southwest Germany) / J. Henkner, J. J. Ahlrichs, S. Downey, M. Fuchs, B. R. James, T. Knopf, T. Scholten, S. Teuber, P. Kühn // Catena. - 2017. - Vol. 155. - P. 93-113.

89. Stratigraphy and age of colluvial deposits indicating Late Holocene soil erosion in northeastern Germany / C. Kapplera, K. Kaisera, P. Tanskib, F. Klosc, A. Füllingd, A. Mrotzeke, M. Sommerf, O. Bens // Catena. - 2018. Vol. 170. - P. 224-245.

90. Crawford, A. J. Charcoal morphometry for paleoecological analysis: the effects of fuel type and transportation on morphological parameters / A. J. Crawford, C. M. Belcher // Applications in plant sciences. - 2014. - Vol. 2 (8).

91. Charcoal records of fire history in the Holocene loess-soil sequences over the southern Loess Plateau of China / C. C. Huang, J. Pang, S. E. Chen, H. Su, J. Han, Y. Cao, Z. Tan // Palaeogeography, Palaeoclimatology, Palaeoecology. - 2006. - Vol. 239 (1-2). - P. 28-44.

92. Li, X. Holocene agriculture in the Guanzhong Basin in NW China indicated by pollen and charcoal evidence / X. Li, X. Shang, J. Dodson, X. Zhou // Holocene. - 2009. - Vol. 19 (8). - P. 1213-1220.

93. Климатические смены на территории юга Дальнего Востока в позднем плейстоцене-голоцене / А. М. Короткий, Т. А. Гребенникова, В. С. Пушкарь, Н. Г. Разжигаева, В. Г. Волков, Л. А. Ганзей, Л. М. Мохова, В. Б. Базарова, Т. Р. Макарова // Вестник ДВО РАН. - 1997. - № 3. - С. 121-143.

94. From young to adult trees: How spatial patterns of plants with different life strategies change during age development in an old-growth Korean pine-broadleaved forest / A. Omelko, O. Ukhvatkina, A. Zhmerenetsky, L. Sibirina, T. Petrenko, M. Bobrovsky // Forest Ecology and Management. - 2018. - Vol. 411. - P. 46-66. 
95. Крылов, Г. В. Кедр / Г. В. Крылов, Н. К. Таланцев, Н. Ф. Козакова. - Москва : Лесная промышленность, 1983. $-215 \mathrm{c}$.

96. Climate and human influences on globalbiomass burning over the past two millenni / J. R. Marlon, P. J. Bartlein, C. Carcaillet, D. G. Gavin, S. P. Harrison, P. E. Higuera, F. Joos, M. J. Power, I. C. Prentice // Nat. Geosci. 2008. - Vol. 1. - P. 697-702.

97. Ruddiman, W. F. The Anthropocene / W. F. Ruddiman // Annu. Rev. Earth Planet Sci. - 2013. - Vol. 41. - P. 45-68.

98. 7000-year human legacy of elevation-dependent European fire regimes / B. Vannière, O. Blarquez, D. Rius, E. Doyen, T. Brücher, D. Colombaroli, S. Connor, A. Feurdean, T. Hickler, P. Kaltenrieder, C. Lemmen, B. Leys, C. Massa, J. Olofsson // Quat. Sci. Rev. - 2016. - Vol. 132. - P. 206-212.

99. Шлотгауэр, С. Д. Воздействие пирогенного фактора на состояние растительного покрова в бассейне Амура / С. Д. Шлотгауэр, М. В. Крюкова // Вестник Дальневосточного отделения Российской академии наук. 2008. - № 1. - C. 59-68.

100. Omelko, A. M. Disturbance history and natural regeneration of an old-growth Korean pine-broadleaved forest in the Sikhote-Alin mountain range, Southeastern Russia / A. M. Omelko, O. N. Ukhvatkina, A. A. Zhmerenetsky // Forest Ecology and Management. - 2016. - Vol. 360. - P. 221-234.

101. Rius, D. Holocene fire regime changes from multiple-site sedimentary charcoal analyses in the Lourdes basin (Pyrenees, France) / D. Rius, B. Vannière, D. Galop, H. Richard // Quat. Sci. Rev. - 2011. - Vol. 30. P. 1696-1709.

102. Holocene fire activity during low-natural flammability periods reveals scale-dependent cultural human-fire relationships in Europe / E. Dietze, M. Theuerkauf, K. Bloom, A. Brauer, W. Dörfler, I. Feeser, M. KarpińskaKołaczek // Quaternary Science Reviews. - 2018. - Vol. 201. - P. 44-56.

103. Kaplan, J. O. Large scale Anthropogenic reduction of forest cover in last glacial maximum Europe / J. O. Kaplan, M. Pfeiffer, J. C. A. Kolen, B. A. S. Davis // PloS One. - 2016. - Vol. 11.

104. Пирогенные события на юге Дальнего Востока в позднем плейстоцене-голоцене / В. Б. Базарова, Н. Г. Разжигаева, Л. А. Ганзей, Т. А. Копотева, Л. М. Мохова, А. М. Паничев, М. А. Климин // География и природные ресурсы. - 2017. - № 4. - С. 122-132.

\section{References}

1. Flannigan M. Cantin A. S., De Groot W. J., Wotton M., Newbery A., Gowman L. M. Forest Ecology and Management. 2013, vol. 294, pp. 54-61.

2. Moritz M. A., Batllori E., Bradstock R.A., Gill A. M., Handmer J., Hessburg P. F., Leonard J., McCaffrey S., Odion D. C., Schoennagel T., Syphard A. D. Nature. 2014, vol. 515 (7525), p. 58.

3. Marlon J. R., Bartlein P. J., Daniau A. L., Harrison S. P., Maezumi S. Y., Power M. J., Tinner W., Vanniére B. Quaternary Science Reviews. 2013, vol. 65, pp. 5-25.

4. Whitlock C., Higuera P. E., McWethy D. B., Briles C. E. The Open Ecology Journal. 2010, vol. 3(1), pp. 6-23.

5. Przhevalsky N. M. Puteshestviye v Ussuriyskom kraye v 1867-1869 gg. [Journey to the Ussuri region in $1867-$ 1869]. St. Petersburg, 1870, 348 p.

6. Lesa Dal'nego Vostoka glazami pervoprokhodtsev [Forests of the Far East through the eyes of pioneers]. Ed. Yu. I. Manko. St. Petersburg: Izd. D.V. Lvov, 2016, 512 p.

7. Komarov V. L. Tipy rastitelnosti Yuzhno-Ussuriyskogo kraya [Types of Vegetation of the South Ussury Region]. Pereselencheskoye upravleniye, 1917, 216 p.

8. Kolesnikov B. P. Trudy Sikhote-Alinskogo zapovednika [Sikhote-Alin Nature Reserve proceedings]. 1938, vol. 1, pp. 25-207

9. Kolesnikov B. P. Kedrovyye lesa Dal'nego Vostoka [Cedar pine forests of the Far East]. Moscow-Leningrad : Izd-vo AN SSSR, 1956, $261 \mathrm{p}$.

10. Kolesnikov B.P. Dalniy Vostok [Far East]. Moscow: Izd-vo AN SSSR, 1961, pp. 183-298.

11. Shemetova N. S. Kedrovo-shirokolistvennyye lesa i ikh gari na vostochnykh sklonakh Srednego Sikhote-Alinya [Cedar pine-deciduous forests and their ashes on the eastern slopes of the Middle Sikhote-Alin]. Vladivostok, 1970, $104 \mathrm{p}$.

12. Komarova T. A. Poslepozharnyye suktsessii v lesakh yuzhnogo Sikhote-Alinya [Post-fire successions in the forests of the southern Sikhote-Alin]. Vladivostok: Dalnauka, 1992, 224 p.

13. Pozhary i ikh vliyaniye na prirodnyye ekosistemy Tsentralnogo Sikhote-Alinya [Fires and their impact on the natural ecosystems of Central Sikhote-Alin]. Eds. B. S. Petropavlovskiy, A. A. Astafyev. Vladivostok: Dalnauka, 2010, 264 p.

14. Korotkiy A. M., Karaulova L. P., Troitskaya T. S. Chetvertichnyye otlozheniya Primorya: Stratigrafiya i paleogeografiya [Quaternary deposits of Primorye: Stratigraphy and paleogeography]. Novosibirsk: Nauka, 1980, 234 p.

15. Golubeva L. V., Karaulova L. P. Rastitel'nost' i klimatostratigrafiya plě̌stotsena i golotsena yuga Dalnego Vostoka SSSR [Vegetation and climate stratigraphy of the Pleistocene and Holocene of the south of the Far East of the USSR]. Moscow: Nauka, 1983, 143 p.

16. Korotky A. M., Korobov V. V., Skrylnik G. P. Anomalnyye prirodnyye protsessy i ikh vliyaniye na sostoyaniye geosistem yuga Rossiiyskogo Dalnego Vostoka [Anomalous natural processes and their influence on the state of the geosystems of the south of the Russian Far East]. Vladivostok: Dalnauka, 2011, 265 p. 
17. Aleshinskaya Z.V., Bolikhovskaya N.S., Bolikhovsky V.F. Doklady AN SSSR [Reports of Academy of Sciences of the USSR]. 1980, vol. 254, no. 4, pp. 949-963.

18. Belyanin P. S. Geografiya i prirodnyye resursy [Geography and natural resources]. 2013, no. 1, pp. $105-111$.

19. Razzhigayeva N. G., Ganzey L. A., Grebennikova T. A., Mokhova L. M., Panichev A. M., Kopoteva T. A., Arslanov Kh. A., Starikova A. A., Krupskaya V. V., Maksimov F. E. Tikhookeanskaya geologiya [Pacific geology]. 2016, vol. 35, no. 5, pp. 86-100.

20. Razzhigayeva N. G., Ganzey L. A., Panichev A. M., Arslanov Kh. A., Mokhova L. M., Kopoteva T. A., Kudryavtseva Y. P., Grebennikova T. A., Makarova T. R., Maksimov F. E., Petrov A. Yu. Biodiversity and Environment of Far East Reserves. 2016, no. 1 (8), pp. 173-210.

21. Razzhigayeva N. G., Ganzey L. A., Panichev A. M., Grebennikova T. A., Mokhova L. M., Kopoteva T. A., Kudryavtseva Ye. P., Arslanov Kh. A., Maksimov F. E., Starikova A. A., Zakusin S. V. Geofizicheskiye protsessy i biosfera [Geophysical processes and biosphere]. 2016, vol. 15, no. 3, pp. 35-66.

22. Razzhigayeva N. G., Ganzey L. A., Mokhova L. M., Grebennikova T.A., Panichev A. M., Kopoteva T. A., Kudryavtseva E. P., Arslanov Kh. A., Maksimov F. E., Starikova A. A., Petrov A. Yu. Geografiya i prirodnyye resursy [Geography and natural resources]. 2017, no. 3, pp. 127-138.

23. Razzhigayeva N. G., Ganzey L. A., Mokhova L. M., Makarova T. R., Panichev A. M., Kopoteva T. A., Kudryavtseva E. P., Arslanov Kh. A., Maksimov F. E., Petrov A. Yu., Krupskaya V. V. Izvestiya Rossiyskoy akademii nauk. Seriya geograficheskaya [Proceedings of the Russian Academy of Sciences. Geographical series.]. 2017 , no. 4, pp. 97-111.

24. Lehtonen H., Huttunen P., Zetterberg P. Annales Botanici Fennici. 1996, vol. 33, pp. 257-263.

25. Niklasson M., Drakenberg B. Biological Conservation. 2001, vol. 101 (1), pp. 63-71.

26. Conedera M., Tinner W., Neff C., Meurer M., Dickens A. F., Krebs P. Quaternary Science Reviews. 2009, vol. 28 (5-6), pp. 555-576.

27. Stambaugh M. C., Marschall J. M., Abadir E. R., Jones B. C., Brose P. H., Dey D. C., Guyette P. R. Ecosphere. 2018, vol. 9 (5), e02222.

28. Clark J. S. Quaternary Research. 1988, vol. 30, pp. 81-91.

29. Clark J. S., Lynch J., Stocks B. J. Holocene. 1998, vol. 8, pp. 19-29.

30. Carcaillet C., Thinon M. Rev. Palaeobot. Palynol. 1996, vol. 91 (1-4), pp. 399-416.

31. Ohlson M., Tryterud E. Holocene. 2000, vol. 10 (4), pp. 519-525

32. Tinner W., Hofstetter S., Zeugin F., Conedera M., Wohlgemuth T., Zimmermann L., Zweifel R. Holocene. 2006 , vol. 16 (2), pp. 287-292.

33. Talon B. Holocene. 2010, vol. 20 (1), pp. 35-44.

34. Touflan P., Talon B., Walsh K. Holocene. 2010, vol. 20 (1), pp. 45-52.

35. Ohlson M., Dahlberg B., Økland T., Brown K. J., Halvorsen R. Nature Geoscience. 2009, vol. 2 (10), pp. 692.

36. Nelle O., Robin V., Talon B. Quaternary International. 2013, vol. 289, pp. 1-4.

37. Robin V., Nelle O. Veg. Hist. Archaeobotany. 2014, vol. 23 (1), pp. 51-65.

38. Ohlson M., Ellingsen V. M., del Olmo M. V., Lie M. H., Nybakken L., Asplund J. Holocene. 2017, vol. 27 (3), pp. 397-403.

39. Bocharnikov V. N., Glushchenko Yu. N., Mikhailov K. E., Egidarev E. G. Biodiversity and Environment of Far East Reserves. 2016, no. 1 (8). pp. 3-24.

40. Bikin. NL53-5. List from Eastern Siberia AMS Topographic Maps. Series N504, U.S. Army Map Service, 1950. A Univercity of Texas libraries. Available at: http://legacy.lib.utexas.edu/maps/ams/eastern_siberia/txu-oclc6572926-nl53-5.jpg (accessed at 11.12.2018)

41. Ekosistemy basseyna r. Bikin: sreda, chelovek, upravleniye [Ecosystems of the Bikin River Basin: Environment, Man, Management]. Vladivostok: DVO RAN, 1997, 176 p.

42. Atlas lesov Primorskogo kraya [Atlas of forests of Primorsky Krai]. Vladivostok: DVO RAN, 2005,76 p.

43. Krishtofovich A.N. Materialy po istorii flory i rastitelnosti SSSR [Data on the history of flora and vegetation of the USSR]. Moskva, Leningrad: Izd-vo AN SSSR. 1946, vol. II, pp. 21-87.

44. Krestov P. V. For. Veg. Northeast Asia. Dordrecht, 2003, pp. 93-180.

45. Spisok vyyavlennykh obyektov arkheologicheskogo naslediya, raspolozhennykh na territorii Khabarovskogo kraya [List of archaeological heritage sites located on the territory of the Khabarovsk Territory]. Prikaz ministerstva kultury Khabarovskogo kraya ot 23.10.2015. Available at: https://pandia.ru/text/80/032/2700.php (accessed at 11.12.2018)

46. Atlas Primorskogo kraya [Atlas of Primorsky Krai]. Eds. E. N. Nazdratenko, N. M. Tsymbalenko. Vladivostok: DV AGP, 1998.

47. Dyakova O. V. Gosudarstvo Bokhay: arkheologiya, istoriya, politika [The State of Bohai: Archeology, History, Politics]. Moscow: Nauka - Vost. lit., 2014, 318 p.

48. China Handbook Editorial Committee, China Handbook Series: History (trans., Dun J. Li), Beijing, 1982, pp. 89-188.

49. Panichev A. M. Bikin. Tayga i lyudi [Taiga and people]. Vladivostok: izd-vo DVGTU, 2005, 250 p.

50. Shibnev B. K. Zhivoy Bikin. Neravnodushnyye zapiski: rasskazy, ocherki, staty [Lively Bikin. Not indifferent notes: stories, essays, articles]. Vladivostok: AVK «Apelsin», 2006. 329 p.

51. Reimer P. J., Bard E., Bayliss A., Beck J. W., Blackwell P. G., Bronk Ramsey C., Buck C. E., Cheng H., Edwards R. L., Friedrich M., Grootes P. M., Guilderson T. P., Haflidason H., Hajdas I., Hatté C., Heaton T. J., Hoffmann D. L., 
Hogg A. G., Hughen K. A., Kaiser K. F., Kromer B., Manning S. W., Niu M., Reimer W., Richards D. A., Scott E. M., Southon J. R., Staff R. A., Turney C. S. M., van der Plicht J. Radiocarbon. 2013, vol. 55, pp. 18691887.

52. Arno S. F., Sneck K. M. USDA For. Serv. Gen. Tech. Rep. 1977, INT-42.

53. Zackrisson O. Oikos. 1977, vol. 29, pp. 22-32.

54. Niklasson M., Granström A. Ecology. 2000, vol. 81, pp. 1484-1499.

55. Schulze E. D., Wirth C., Mollicone D., Ziegler W. Oecologia. 2005, vol. 146 (1), pp. 77-88.

56. Wallenius T., Larjavaara M., Heikkinen J., Shibistova O. Journal of Wildland Fire. 2011, vol. 20 (2), pp. $248-254$.

57. Barrett S. W., Arno S. F. Gen. Tech. Rep. INT-244. Ogden, UT: US Department of Agriculture, Forest Service, Intermountain Research Station, 1988, vol. 15, p. 244.

58. Couillard P. L., Tremblay J., Lavoie M., Payette S. Forest Ecology and Management. 2019, vol. 433, pp. $376-385$.

59. Ponomarenko E. V. Suktsessionnyye protsessy v zapovednikakh Rossii i problemy sokhraneniya biologicheskogo raznoobraziya [Succession processes in Russian nature reserves and problems of biodiversity conservation]. Eds. O. V. Smirnova, E. S. Shaposhnikov. Sankt-Peterburg: RBO, 1999, pp. 34-57.

60. Gavin D. G. Can. J. For. Res. 2003, vol. 33 (12), pp. 2514-2518.

61. Gavin D. G., Brubaker L. B., Lertzman K. P. Ecology. 2003, vol. 84 (1), pp. 186-201.

62. Talon B., Payette S., Filion L., Delwaide A. Quat. Res. 2005, vol. 64, pp. 36-43.

63. Sanborn P., Geertsema M., Jull A. T., Hawkes B. Holocene. 2006, vol. 16 (3), pp. 415-427.

64. Bobrovsky M. V. Lesnye pochvy Evropeyskoy Rossii^ bioticheskie I antropogennye faktory formirovaniya [Forest soil of European Russia: biotic and anthropogenic factors in pedogenesis]. Moscow: KMK Scientific Press Ltd, 2010, 359 p.

65. Bobrovsky M., Loyko S. Russian Journal of Ecosystem Ecology. 2016, vol. 1 (1), pp. 1-22.

66. Embleton-Hamann C. Catena. 2004, vol. 57, pp. 175-188.

67. Šamonil P., Schaetzl R. J., Valtera M., Golias V., Baldrian P., Vasickova I., Adam D., Janik D., Hort L. For. Ecol. Manag. 2013, vol. 307, pp. 123-135.

68. Bobrovsky M. V., Kupriaynov D. A., Khanina L. G. Quaternary International. 2019, in press.

69. Beatty S. W., Stone E. L. Can. J. For. Res. 1986, vol. 16 (3), pp. 539-548.

70. Voskresenskiy S. S. Dinamicheskaya geomorfologiya. Formirovaniye sklonov [Dynamic geomorphology. Slopes formation]. Moscow: Izd-vo MGU, 1971, 229 p.

71. Lutz H. T. J. Sci. 1960, no. 10, pp. 752-756.

72. Pawlik Ł., Šamonil P. Earth-Science Reviews. 2018, vol. 178, pp. 257-278.

73. García-Ruiz J. M., Beguería S., Nadal-Romero E., González-Hidalgo J. C., Lana-Renault N., Sanjuán Y. Geomorphology. 2015, vol. 239, pp. 160-173.

74. Malvar M. C., Silva F. C., Prats S. A., Vieira D. C., Coelho C. O., Keizer J. J. Forest ecology and management. 2017, vol. 400, pp. 555-567.

75. Blong R. J., Gillespie R. Nature. 1978, vol. 271, pp. 739-741.

76. Patterson W. A., Edwards K. J., Maguire D. J. Quat. Sci. Rev. 1987, vol. 6, pp. 3-23.

77. Carcaillet C., Perroux A. S., Genries A., Perrette Y. Holocene. 2007, vol. 17 (6), pp. 845-850.

78. Scott A. C. Palaeogeography, Palaeoclimatology, Palaeoecology. 2010, vol. 291, pp. 11-39.

79. Lavee H., Kutiel P., Segev M., Benyamini Y. Geomorphology. 1995, vol. 11(3), pp. 227-234.

80. Certini G. Oecologia. 2005, vol. 143 (1), pp. 1-10.

81. Shakesby R. A., Doerr S. H. Earth-Science Reviews. 2006, vol. 74 (3-4), pp. 269-307.

82. Mataix-Solera J., Cerdā A., Arcenegui V., Jordán A., Zavala L. M. Earth-Science Reviews. 2011, vol. 109 (1-2), pp. 44-60.

83. DeBano L. F. Journal of hydrology. 2000, vol. 231, pp. 195-206.

84. Wondzell S. M., King J. G. Forest Ecology and Management. 2003, vol. 178, pp. 75-87.

85. Johansen M. P., Hakonson T. E., Breshears D. D. Hydrological processes. 2001, vol. 15 (15), pp. $2953-2965$.

86. Santin C., Doerr S. H., Kane E. S., Masiello C. A., Ohlson M., de la Rosa J. M., Preston C. M., Dittmar T. Global Change Biology. 2016, vol. 22 (1), pp. 76-91.

87. Larsen A., Robin V., Heckmann T., Fülling A., Larsen J. C., Bork H. R. Holocene. 2016, vol. 26 (8), pp. 12481261.

88. Henkner J., Ahlrichs J. J., Downey S., Fuchs M., James B. R., Knopf T., Scholten T., Teuber S., Kühn P. Catena. 2017, vol. 155, pp. 93-113.

89. Kapplera C., Kaisera K., Tanskib P., Klosc F., Füllingd A., Mrotzeke A., Sommerf M., Bens O. Catena. 2018, vol. 170, pp. 224-245.

90. Crawford A. J., Belcher C. M. Applications in plant sciences. 2014, vol. 2(8), 1400004.

91. Huang C. C., Pang J., Chen S. E., Su H., Han J., Cao Y., ... Tan Z. Palaeogeography, Palaeoclimatology, Palaeoecology. 2006, vol. 239 (1-2), pp. 28-44.

92. Li X., Shang X., Dodson J., Zhou X. Holocene. 2009, vol. 19 (8), pp. 1213-1220.

93. Korotkiiy A. M., Grebennikova T. A., Pushkar V. S., Razzhigayeva N. G., Volkov V. G., Ganzeiy L. A., Mokhova L. M., Bazarova V. B., Makarova T. R. Vestnik DVO RAN [Bulletin of the Far East Branch of the Russian Academy of Sciences]. 1997, no. 3, pp. 121-143. 
94. Omelko A., Ukhvatkina O., Zhmerenetsky A., Sibirina L., Petrenko T., Bobrovsky M. Forest Ecology and Management. 2018, vol. 411, pp. 46-66.

95. Krylov G. V., Talantsev N. K., Kozakova N. F. Kedr [Cedar Pine]. Moscow: Lesnaya promyshlennost, 1983, $215 \mathrm{p}$.

96. Marlon J. R., Bartlein P. J., Carcaillet C., Gavin D. G., Harrison S. P., Higuera P. E., Joos F., Power M. J., Prentice I. C. Nat. Geosci. 2008, vol. 1, pp. 697-702.

97. Ruddiman W. F. Annu. Rev. Earth Planet Sci. 2013, vol. 41, pp. 45-68.

98. Vannière B., Blarquez O., Rius D., Doyen E., Brücher T., Colombaroli D., Connor S., Feurdean A., Hickler T., Kaltenrieder P., Lemmen C., Leys B., Massa C., Olofsson J. Quat. Sci. Rev. 2016, vol. 132, pp. $206-212$.

99. Shlotgauer S. D., Kryukova M. V. Vestnik DVO RAN [Bulletin of the Far East Branch of the Russian Academy of Sciences]. 2008, no. 1, pp. 59-68.

100. Omelko A. M., Ukhvatkina O. N., Zhmerenetsky A. A. Forest Ecology and Management. 2016, vol. 360, pp. 221234.

101. Rius D., Vannière B., Galop D., Richard H. Quat. Sci. Rev. 2011, vol. 30, 1696e1709.

102. Dietze E., Theuerkauf M., Bloom K., Brauer A., Dörfler W., Feeser I., ... Karpińska-Kołaczek M. Quaternary Science Reviews. 2018, vol. 201, pp. 44-56.

103. Kaplan J. O., Pfeiffer M., Kolen J. C. A., Davis B. A. S. PloS One. 2016. vol. 11, e0166726.

104. Bazarova V. B., Razzhigayeva N. G., Ganzey L. A., Kopoteva T. A., Mokhova L. M., Panichev A. M., Klimin M. A. Geografiya i prirodnyye resursy [Geography and natural resources]. 2017, no. 4, pp. 122-132. 